\title{
Methods of Wet Cupping Therapy (Al-Hijamah): In Light of Modern Medicine and Prophetic Medicine
}

\section{El Sayed SM ${ }^{1 *}$, Mahmoud $\mathrm{HS}^{2}$ and Nabo $\mathrm{MMH}^{3,4}$}

${ }^{1}$ Department of Medical Biochemistry, Sohag Faculty of Medicine, Sohag University, Egypt

${ }^{2}$ World Federation of Alternative and Complementary Medicine, Cairo Regional Headquarter, Cairo, Egypt

${ }^{3}$ Department of Pediatrics, Sohag Teaching Hospital, Sohag, Egypt

${ }^{4}$ Division of Pediatric cardiology, Department of Pediatrics, Maternity and Children Hospital, King Abdullah Medical City, Al-Madinah Al-Munawwarah, Kingdom of Saudi Arabia

\begin{abstract}
Cupping therapy is a simple, effective and economic treatment. Cupping therapy is a formal treatment in Chinese hospitals and in some European countries. Here, we review history of wet cupping therapy and its two distinct methodologies. First method is puncturing and cupping (PC) method that includes five steps: skin demarcation, sterilization, puncturing, cupping and sterilization. Second method is cupping, puncturing and cupping (CPC) method that includes six steps: skin demarcation, sterilization, first cupping, puncturing, second cupping and sterilization. CPC method predominates in the Arabic world, while PC method has a worldwide distribution. We report here that our detailed evidence-based analysis of both methods reveals many novel advantages in the CPC method over the PC method. CPC method has a better analgesic effect and benefits more from the viscoelastic nature of the skin. During the first cupping step in the CPC method (not present in the PC method), a fluid mixture containing causative pathological substances (CPS) is collected inside skin uplifting due to the effect of negative pressure of sucking cups. CPS differs from disease to disease according to disease etiology and pathogenesis. That fluid mixture contains collected interstitial fluids with CPS, filtered fluids (from blood capillaries) with CPS, hemolyzed blood cells (hemolysed RBCs, WBCs and platelets). That fluid mixture does not contain intact blood cells as their sizes are much bigger than sizes of pores of skin capillaries and cannot be filtered. The fluid mixture is totally excreted in next steps. We review here that wet cupping therapy is a highly recommended treatment in prophetic medicine, medicine related to Prophet Mohammad peace be upon him who said: "The best among what you use in therapy is Al-hijamah (CPC method of wet cupping therapy)".
\end{abstract}

In conclusion, CPC method is better than PC method in clearing blood and interstitial spaces from CPS. Standardization of methodologies of cupping therapy seems essential to gain optimal therapeutic outcomes.

Keywords: Cupping therapy; Prophetic medicine; CPC method; PC method; Boyle's law; CPS

Abbreviations: PC Method: Puncturing and Cupping Method; CPC Method: Cupping, puncturing And Cupping Method; CPS: Causative Pathological Substances; GIT: Gastrointestinal Tract; ITP: Idiopathic Thrombocytopenic Purpura; RBCs: Red Blood Cells; TCM: Traditional Chinese Medicine; WBCs: White Blood Cells

\section{Introduction}

Cupping therapy is a simple procedure in which negative pressure is applied to the skin through sucking cups (dry cupping therapy) [1]. Many types of cupping therapy are described in the literature including dry cupping therapy, wet cupping therapy, medicinal cupping therapy, moving cupping therapy and others [2]. The most important type of wet cupping therapy seems to be Al-hijamah (method of wet cupping therapy practiced in prophetic medicine). As we will show here, unlike most conventional treatment modalities, wet cupping therapy is an excretory form of therapy not an introductory one i.e. wet cupping therapy uses negative pressure suctioning and skin pricking to open the skin barrier and excrete a bloody mixture of fluids with soluble wastes and causative pathological substances (CPS). Second negative pressure suctioning completes the process of waste excretion. Unfortunately, medical research related to cupping therapy does not cover its importance. Cupping therapy is practiced officially in hospitals in China [3] and is considered very familiar in some European countries $[4,5]$. Current methodologies used for cupping therapy differ according to the type of cupping therapy e.g. dry cupping method differs from medicinal cupping method [6]. In this review article, we shed light on the two methods of wet cupping therapy reported in the literature to discuss which is more beneficial to be standardized in practicing cupping therapy in treating so many diseases as we will mention later in this article.

\section{History of cupping therapy}

Cupping therapy is being practiced nowadays in many countries all over the world including Germany, Norway, Denmark, Saudi Arabia, Egypt, India, China and other countries. German people are familiar with cupping therapy [4] and so are Danish and Norwegian peoples where those European societies already have a shift in attitude to include complementary medicine within the conventional health care system [5].

The exact origin of cupping therapy is a matter of controversy. Chinese scientists report in their literature that cupping therapy is a

*Corresponding author: Salah Mohamed El Sayed, Department of Medical Biochemistry, Sohag Faculty of Medicine, Sohag University, Egypt, Tel: +20934-602-963; Fax: +2-0934-602-963; E-mail: salahfazara@yahoo.com, drsalahpediatr@yahoo.com

Received March 19, 2013; Accepted April 12, 2013; Published April 15, 2013

Citation: El Sayed SM, Mahmoud HS, Nabo MMH (2013) Methods of Wet Cupping Therapy (Al-Hijamah): In Light of Modern Medicine and Prophetic Medicine. Altern Integ Med 2: 111. doi:10.4172/2327-5162.1000111

Copyright: (c) 2013 El Sayed SM, et al. This is an open-access article distributed under the terms of the Creative Commons Attribution License, which permits unrestricted use, distribution, and reproduction in any medium, provided the original author and source are credited. 
part of the traditional Chinese medicine (TCM) dating back to at least 2,000 years [2].

In the middle east, Arabic writers report that cupping therapy dates back to 3500 B.C. (5500 years ago), where Assyrians were the first Arab population to use primitive tools as animal horns and bamboo wood for cupping therapy then the Chinese physician, Jee Hong (381281 B.C.) was among the leaders in that art. Arabic civilization termed cupping therapy, Al-hijamah therapy (which means in Arabic: to restore to the original size), where it was used in treating hypertension, polycythemia, headache, migraine and drug intoxication. They diagnosed polycythemia whenever there was an exaggeration of the pink color of the skin [7]. Interestingly, venesection (phlebotomy) is still being used currently in hospitals for treating polycythemia, where blood is drawn out and is replaced by saline infusion [8] .

Ancient Egyptians were reported to practice cupping therapy earlier than many old civilizations, where cupping therapy was one of the oldest known medical therapies in ancient Egypt. The first report of using cupping therapy in ancient Egypt dates back to 1550 B.C. (more than 3500 years ago) where drawings on the famous Egyptian papyrus paper (Ebers paper) and ancient Egyptian temples showed that Egyptians were advanced in treatment using cupping therapy. Cupping therapy was also used in ancient Greek medicine $[9,10]$.

In 400 B.C., Herodotus (a Greek historian) recorded that the ancient Egyptian physicians who recommended the application of sucking cups to the body already used both wet cupping therapy and dry cupping therapy. Diseases treated by cupping therapy included headache, lack of appetite, maldigestion, fainting, abscess evacuation, narcolepsy (repeated sleepy desires) and others [11].

In 3300 BC, in Ancient Macedonia, cupping therapy had been used since prehistoric times to treat diseases and health disorders $[12,13]$.

In the United States, there is a progressive increase in the use of cupping therapy and other types of complementary medicine [14]. In a recent report from Harvard medical school about pediatric patients suffering from chronic severe pain, authors reported that cupping and acupuncture treatment were pleasant and helpful for pain treatment [15].

Currently, most widely used practice for cupping therapy is in China. Cupping therapy is considered by Chinese to be part of the TCM. Chinese hospitals recognized cupping therapy as a formal modality of treatment since 1950 [3]. Currently, medical practitioners in China and Mongolia are practicing cupping therapy for treating hypertension, neck pain, headache, chronic hepatitis, ophthalmic diseases, skin diseases and infectious diseases [16]

Loukas et al. recently reported that knowledge gained from religious texts (Qur'an and Hadeeth) may guide attention of researchers to start research and get some benefits when comparing such knowledge with modern medical knowledge. Prophetic medicine is the medical knowledge gained from sayings, advices and teachings of Prophet Mohammad peace be upon him, $[17,18]$ which recommended many lines of treatment as cupping therapy: (If there is a benefit in any of your treatment modalities, benefit will be in the blade puncture in cupping therapy, a gulp of honey and cauterizing, but I do not like cauterization) $[17,18]$.

\section{Cupping therapy is effective in treatment of incurable medical conditions}

Cupping therapy was reported to treat medical conditions as herpes zoster [19], vitiligo [20], hypertension [1,21,22], rheumatoid arthritis $[23,24]$, headache and migraine $[13,25]$. Cupping therapy was reported to relieve pain of dysmenorrhoea [26], acute trigeminal neuralgia [27], chronic osteoarthritis [10], carpal tunnel syndrome [4], fibrositis [28], firomyalgia [6,29-31], cervical spondylosis, lumbar disc herniation [3], brachialgia paraesthetica nocturna [32], chronic non-specific neck pain [33-35], persistent non-specific low back pain [36] and pain of acute gouty arthritis [37].

Wet cupping therapy (Al-hijamah) has solid scientific and medical bases according to Taibah theory suggested by Salah M. El Sayed. Wet cupping therapy is as an artificial surgical excretory procedure that clears blood and interstitial fluids from CPS. It opens skin barrier, enhances natural excretory functions of the skin, enhances immunity and increases filtration at both capillary ends to clear blood from CPS to restore physiology and homeostasis. Moreover, it was reported that compression pressure exerted on the skin for more than few seconds (as that exerted by the outline of sucking cups during Al-hijamah) may benefit patients through the occurrence of reactive hyperemia phenomenon. In this phenomenon, vascular compression causes a decrease in blood supply to the skin for few minutes resulting in accumulation of vasodilator chemicals. As soon as vascular compression is removed, blood flow to skin dramatically increases, which is called hyperemia [38]. This may bring more blood to the skin circulation to be filtered and cleared during next steps of Al-hijamah.

Interestingly, Hany Salah was the first to report the best anatomical sites in human body for doing cupping therapy in treating different diseases [39].

As there are several methodologies to practice cupping therapy, proper choice and selection of best methods of cupping therapy for treating diseases seems mandatory.

Dry cupping therapy may be less beneficial than wet cupping therapy due to lack of excretion of CPS in dry cupping therapy (Table 1). Wet cupping therapy needs proper discussion of its available methodologies to optimize its therapeutic outcomes.

\section{Technical Methods Used for Performing Cupping Therapy}

Before discussing the benefits or hazards of cupping therapy, it is strongly advisable to know types of cupping therapy and to revise the steps of wet cupping therapy to standardize the optimal protocol for cupping therapy. Taking Chinese cupping therapy as an example, many different types of cupping therapy are being practiced nowadays in official Chinese hospitals $[3,6]$ as summarized in table 2 .

Concentrating on methods of wet cupping therapy is the aim of this article. Although this issue is vital, it did not receive enough attention when discussing the results of wet cupping treatment. Interestingly, when we reviewed the cupping methodologies reported in the literature, we found minor but important differences among the methodologies used for wet cupping therapy. Two distinct wet cupping methodologies were reported in the literature. Both methods are in agreement with each other as regard the starting steps, which include demarcation of skin points to which cupping therapy should be applied, followed by sterilization at these sites and as regard the last step, which is sterilization. They differ in the order and number of the steps of 


\begin{tabular}{|c|c|c|}
\hline & Dry cupping therapy & Wet cupping therapy \\
\hline Distribution & $\begin{array}{l}\text { Most commonly practiced type of cupping therapy in China. Used } \\
\text { in many parts of the world. }\end{array}$ & $\begin{array}{l}\text { Most commonly practiced type of cupping therapy in the Arabic and } \\
\text { Islamic world e.g. CPC method prevails in Saudi Arabia, while PC } \\
\text { method prevails in China and in many parts of the world. }\end{array}$ \\
\hline Types & One type & 2 types: CPC method and PC method. \\
\hline Dry cupping therapy & Can be done as a single treatment & $\begin{array}{l}\text { Included as the first part of wet cupping therapy in the CPC method } \\
\text { but not included in the methodology of the PC method of wet cupping } \\
\text { therapy. }\end{array}$ \\
\hline Skin puncturing & Not done & Done \\
\hline Number of technical steps & One step (only cupping) & $\begin{array}{l}2 \text { steps in PC (puncturing and cupping) method and } 3 \text { steps in CPC } \\
\text { (cupping, puncturing and cupping) method }\end{array}$ \\
\hline and wastes & $\begin{array}{l}\text { Not done i.e. retention of fluids and wastes. Only dilution and } \\
\text { redistribution of noxious soluble substances may occur away from } \\
\text { pain receptors and pain-sensitive structures. }\end{array}$ & $\begin{array}{l}\text { Done i.e. excretion of fluids and excretion of wastes after being diluted } \\
\text { and redistributed in collected fluids inside skin upliftings (better in the } \\
\text { CPC than in the PC method) }\end{array}$ \\
\hline $\begin{array}{l}\text { As a prophetic medicine } \\
\text { recommendation }\end{array}$ & $\begin{array}{l}\text { Dry cupping therapy was not done as a single treatment in } \\
\text { prophetic era. } \\
\text {. Done as first part of the recommended wet cupping therapy in } \\
\text { prophetic medicine (CPC method=Al-hijamah) }\end{array}$ & $\begin{array}{l}\text { CPC method (Al-hijamah) was recommended and done in prophetic } \\
\text { era and continues to be done until now in Saudi Arabia and other } \\
\text { Islamic countries. }\end{array}$ \\
\hline $\begin{array}{l}\text { Treating pathological } \\
\text { causes }\end{array}$ & $\begin{array}{l}\text { Palliative (as causative excess fluids with soluble CPS are not } \\
\text { excreted). }\end{array}$ & Curative when done properly (CPC method better than PC method) \\
\hline Other names & Retained cupping therapy & Bleeding cupping therapy, Al-Hijamah. \\
\hline
\end{tabular}

Table 1: Differences between Dry Cupping Therapy and Wet Cupping Therapy.

\begin{tabular}{|l|}
\hline Type of cupping therapy \\
\hline 1.Retained cupping (dry cupping therapy) \\
\hline 2. Bleeding cupping (wet cupping) therapy \\
\hline 3. Moving cupping \\
\hline 4. Empty cupping therapy \\
\hline 5. Needle cupping \\
\hline 6. Medicinal (herbal) cupping \\
\hline 7. Water cupping therapy \\
\hline
\end{tabular}

cupping treatment itself i.e. what comes first: cupping step (negative pressure suctioning) or puncturing skin step. The difference in the two methods may reflect different historical origins in both methods of cupping therapy based on the known standard protocols in their countries of origin.

In a Korean review of literature for databases of cupping therapy and also in a Korean study, wet cupping therapy was effective in treating many disease conditions of variable etiologies and pathogeneses $[36,40]$. Authors mentioned steps of wet cupping therapy exactly as it is done in Chinese clinics in which the five steps of wet cupping therapy are: demarcation (marking cupping points by pen), sterilization, puncturing (lanceting skin in $2 \mathrm{~mm}$-depth), cupping (with manual pump suction for few minutes) and sterilization [19]. This method is better to be abbreviated to PC (puncturing and cupping) method. In another Chinese report for treating 140 cases of fibrositis [28] and another Chinese study for treating gouty arthritis using wet cupping therapy, the authors reported the same steps of the PC method [37].

In a German study for treating carpal tunnel syndrome with wet cupping therapy, authors mentioned same steps reported by the previous Chinese studies [4], which give the impression that German physicians got their cupping method from Chinese medicine. Other European peoples use mainly the PC method of wet cupping therapy $[2,5]$.

In the Arab literature, a different six-step method of wet cupping therapy is reported in prophetic medicine which includes an extra step (cupping step before skin puncturing) i.e. steps of the Arabic methodology for wet cupping therapy (Al-hijamah) are skin demarcation, sterilization, cupping, puncturing, cupping and sterilization [41]. This method is better to be abbreviated to CPC (cupping, puncturing and cupping) method. Interestingly, a Chinese report described steps of the currently practiced wet cupping therapy method in Saudi Arabia [42], which is exactly the CPC method as reviewed early in prophetic medicine [41]. Same CPC method was reported by a research group from Iran in a recent article describing cardio protective effects of cupping therapy in experimental animals [43].

Recently, the same CPC method was reported in an Iraqi report, where CPC method of cupping therapy was quite a safe procedure in treating a variety of diseases e.g. back pain, sciatica, joint pain, hypertension, polycythemia and other diseases with reversible skin changes with no side effects [44]. CPC method was also reported also by an Egyptian research group who reported a high beneficial effect of wet cupping therapy in treatment of rheumatoid arthritis [23]. CPC method was reported to treat hypertension by another Iraqi research group [1]. Same CPC method was reported in a study to treat headache and migraine by a research group from Iran [13]. In a study about cupping therapy done recently in Pakistan, authors investigated the differences between venous blood and blood that comes out during wet cupping therapy. Authors practiced CPC method of wet cupping therapy [45]. This may give the impression that the historical root of $\mathrm{CPC}$ method in wet cupping therapy may be of an Arabic origin.

The most important question that arises soon is which methodology 
Citation: El Sayed SM, Mahmoud HS, Nabo MMH (2013) Methods of Wet Cupping Therapy (Al-Hijamah): In Light of Modern Medicine and Prophetic Medicine. Altern Integ Med 2: 111. doi:10.4172/2327-5162.1000111

Page 4 of 16

\begin{tabular}{|c|c|c|}
\hline & $\begin{array}{l}\text { CPC (cupping, puncturing and cupping) method } \\
\text { =Prophetic wet cupping therapy } \\
\text { =Al-hijamah }\end{array}$ & $\begin{array}{l}\text { PC (puncturing and cupping) method } \\
\text { =Chinese wet cupping therapy }\end{array}$ \\
\hline Distribution & $\begin{array}{l}\text { Only method of wet cupping therapy practiced in Saudi Arabia, } \\
\text { middle east and some Islamic countries. }\end{array}$ & Mainly in China and in other parts of the world \\
\hline Vacuum pressure (cupping) & Applied twice & Once \\
\hline Cupping method & $\begin{array}{l}\text { Equals dry cupping+PC cupping } \\
\text { ( } 2 \text { cupping processes) }\end{array}$ & $\begin{array}{l}\text { Equals one cupping process } \\
\text { (PC cupping only) }\end{array}$ \\
\hline After $1^{\text {st }}$ step (Cupping step) & $\begin{array}{l}\text { Only fluids collect containing fragmented blood cells and causative } \\
\text { pathological substances (due to pressure suctioning) and become } \\
\text { trapped under increased pressure and may bulge through skin } \\
\text { surface but cannot escape due to skin barrier } \\
\text { Benefits from the phenomenon of skin reactive hyperemia }\end{array}$ & Does not occur \\
\hline After $2^{\text {nd }}$ step (skin puncturing step) & $\begin{array}{l}\text { Beginning of escape of trapped fluids mixed with blood at puncture } \\
\text { sites }\end{array}$ & $\begin{array}{l}\text { Escape of fresh blood due to puncture trauma (as } \\
\text { occurs in wounds) mixed with little tissue fluids. }\end{array}$ \\
\hline After $3^{\text {rd }}$ step (Cupping step) & $\begin{array}{l}\text { Pressure suctioning causes all collected fluids+some blood to come } \\
\text { out through traumatic punctures }\end{array}$ & $\begin{array}{l}\text { Pressure suctioning helps bleeding to continue and } \\
\text { blood to come out+some tissue fluids to be excreted. }\end{array}$ \\
\hline punctures) & $\begin{array}{l}\text { No. (As collected tissue fluids are nearer to skin surface than blood } \\
\text { capillaries and accumulate under effect of suction pressure applied } \\
\text { to skin. Continuous accumulation of fluids increases pressure inside } \\
\text { skin upliftings leading to immediate escape of fluids upon skin } \\
\text { puncturing and } 2^{\text {nd }} \text { cupping step. }\end{array}$ & $\begin{array}{l}\text { Yes (as tissue fluids are collected after skin } \\
\text { puncturing and are coming out to skin surface with } \\
\text { blood from punctured capillaries. Blood may hinder } \\
\text { fluid accumulation inside skin upliftings leading to } \\
\text { incomplete escape of fluids upon skin puncturing. }\end{array}$ \\
\hline Total time of vacuum application & Long ( $1^{\text {st }}$ and $2^{\text {nd }}$ cupping steps) & Short (1 cupping step) \\
\hline Pain sensation during puncturing & Mild (analgesic effect of $1^{\text {st }}$ cupping step) & Moderate to severe (as in wounds) \\
\hline Fluid extracted in cups & Larger fluid content and less blood & Higher blood content \\
\hline Tapping puncture site to bleed & Not needed & Usually done \\
\hline Fluid collection in skin upliftings & $\begin{array}{l}\text { Skin upliftings form before skin puncturing step and contain only fluids } \\
\text { with fragmented blood cells and causative pathological substances } \\
\text { (intact blood cells do not diffuse through capillary fenestrae due to } \\
\text { size barrier). }\end{array}$ & $\begin{array}{l}\text { Skin upliftings form after skin puncturing step and } \\
\text { contain mainly fresh blood with little fluid (intact blood } \\
\text { comes from punctured capillaries) }\end{array}$ \\
\hline Sequence of events & $\begin{array}{l}1^{\text {st }} \text { cupping creates skin uplifting. puncturing skin causes simultaneous } \\
\text { excretion of tissue fluid mixed with some blood, } \\
2^{\text {nd }} \text { cupping causes more extrusion of both. }\end{array}$ & $\begin{array}{l}\text { Puncturing causes blood excretion and suctioning } \\
\text { creates skin uplifting with excretion of more blood } \\
\text { and some tissue fluids. }\end{array}$ \\
\hline Expected blood clearance effect & $\begin{array}{l}\text { More due to high fluid content (filtered fluids from capillaries+excreted } \\
\text { tissue fluids). CPC method clears interstitial spaces, capillary blood } \\
\text { and lymphatics properly during the whole } 2^{\text {nd }} \text { cupping step until } \\
\text { closure of skin barrier by blood thrombus. }\end{array}$ & $\begin{array}{l}\text { Less. PC method partially clears interstitial spaces, } \\
\text { capillary blood and lymphatics until closure of skin } \\
\text { barrier by blood thrombus due to lack of prior fluid } \\
\text { collection and incomplete transmission of sucking } \\
\text { pressure due to antagonizing effect of bleeding, } \\
\text { adhesions and intervening fluids }\end{array}$ \\
\hline Expected therapeutic effect & Better & Less \\
\hline$\square$ & More (more breaking of tissue adhesions) & Less \\
\hline $\begin{array}{l}\text { Resolving tissue swelling and breaking } \\
\text { adhesion }\end{array}$ & More & Less \\
\hline Removes blood congestion & More & Less \\
\hline
\end{tabular}

Table 3: Differences between CPC (Al-hijamah) and PC Methods of Wet Cupping Therapy.

may carry better therapeutic outcomes for wet cupping therapy: PC method or CPC method?

Proper answering of this question needs prior understanding of the differences and expected sequences of events of both treatment methods of wet cupping therapy.

\section{Evidence-based Analysis of Detailed Steps and Events of Wet Cupping Therapy (CPC Method Versus PC Method)}

Differences between PC and CPC methods of wet cupping therapy can be of therapeutic importance and studying them may help in standardizing wet cupping therapy (Table 3). Based on our understanding to how wet cupping therapy works, evidence-based analysis of steps of wet cupping therapy (CPC method versus PC method) can be done in the next points.

\section{A-Before application of wet cupping therapy}

1- Tissue fluids filtered from the capillary walls cross the interstitial spaces between parenchymal cells to gain access to the lymphatic capillaries to return to the vascular system [46]. Metabolic byproducts [47] and endogenous free radicals [48] may be continuously formed inside cells and excreted into the interstitial fluids in interstitial spaces. Interstitial fluid is in continuous exchange with intravascular fluid compartment (Figure 1A). The exchange process mainly occurs downstream of arterioles in capillaries and postcapillary venules [49]. Based on that, in physiological conditions, cupping therapy may have a preventive benefit through clearing interstitial spaces from any metabolic waste products, free radicals or xenobiotics in interstitial fluids.

2- In pathological conditions, localization of pro-inflammatory substances [50], inflammatory cells [51], toxins, bacteria and harmful biological or chemical substances $[52,53]$ tends to occur at specific sites that differ according to disease type and pathological stage (Figure 1B). At sites of localization, cupping therapy can be applied to facilitate drainage and removal of the CPS and to decrease the excess fluid volume and hence the pressure exerted by interstitial fluids in interstitial spaces.

3- Factors determining the composition of interstitial fluid and 


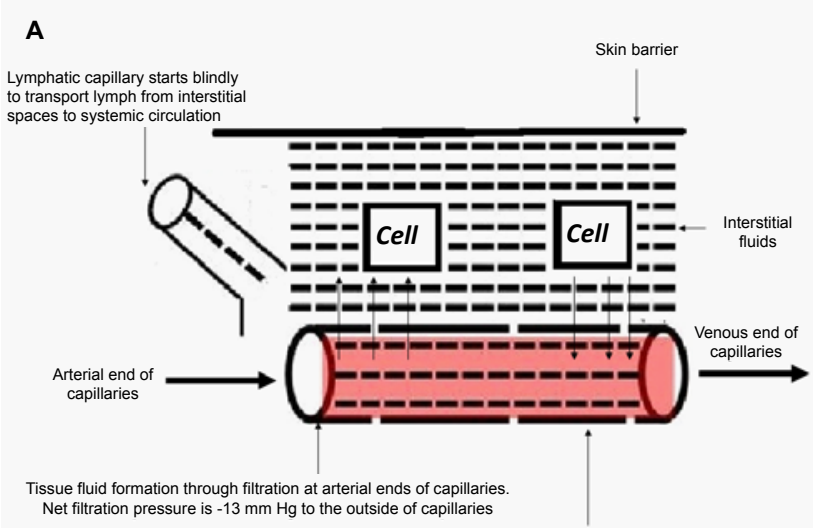

Tissue fluid absorption at venous ends of capillaries. Net absorption pressure is $+7 \mathrm{~mm} \mathrm{Hg}$ to the inside of capillaries

B CPC method PC method

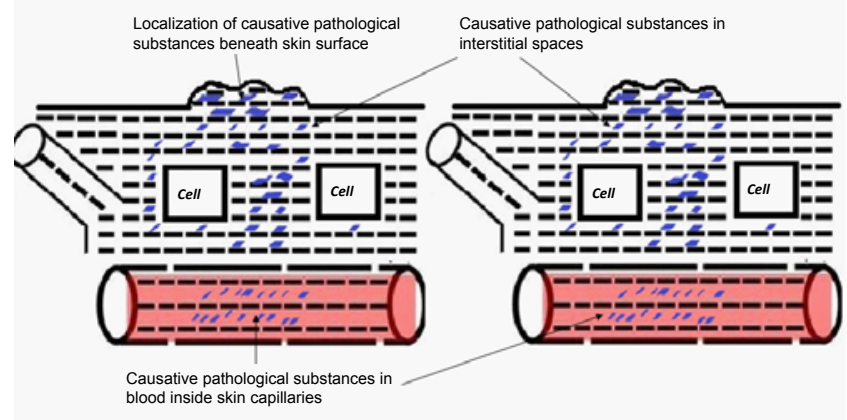

Figure 1: Tissue fluid formation under physiological (A) and pathological (B) conditions.

subsequently the interstitial pressure include the plasma composition, the balance of Starling forces across the capillary wall (principally capillary hydrostatic pressure and plasma protein osmotic pressure), capillary permeability, surface area of capillary endothelium, lymph transport, and the physicochemical properties of the interstitial space matrix. Also, modification, addition or removal of components by peripheral cell metabolism can determine the composition of interstitial fluids [54]. Based on that, cupping therapy may be beneficial in clearing interstitial fluids and restoring normal physiology of interstitial spaces.

4- Pathogenesis of pain includes interstitial hypertension and increased amount of neurotransmitters, such as substance $\mathrm{P}$ and its receptor, calcitonin gene-related peptide and other neurotransmitters in afferent nerves [55]. Based on that, cupping therapy at these localized sites may remove localized fluids, clear interstitial spaces, decrease interstitial hypertension and excrete CPS.

5- Substance $\mathrm{P}$ is an 11-amino acid peptide that is widely distributed in the nervous system of human and animal species. Substance P is functionally linked to pain [56]. Substance P releases histamine [57] leading to increased cutaneous capillary permeability without any fluid leakage through intact skin barrier. Substance P induces release of antigen-evoked mediators [58], tumor necrosis factor-alpha [59] and leukotrienes [60], which act as inflammatory mediators to enhance pain and tissue swelling. The interstitium plays a role in the development of edema in burns and in the induction of initial swelling in inflammation [61]. Based on that, pain conditions may benefit from cupping therapy through excretion of fluids containing the above-mentioned CPS (Figure 2).

6-Nerve endings (nociceptors that transmit pain signals) become sensitized during tissue damage or inflammation. Goodwin gave the term inflammatory soup to the mixture of inflammatory cells as macrophages and lymphocytes together with chemical mediators e.g. substance $\mathrm{P}$ histamine, serotonin, bradykinin, prostaglandins and cytokines (Figure 2) in the peripheral tissues, that increase in the responsiveness of $\mathrm{A}$ delta and $\mathrm{C}$ nerve fibres, which conduct pain signals at different rates [62].

7- Excretory functions of the skin depend on its histological structure and its large surface area. Skin excretes many drugs, heavy metals, chemicals and endogenous toxic compounds. Skin has a drug metabolizing function [63], drug biotransformation function [64], antioxidant function [65] in addition to the excretory functions exerted by skin appendages e.g. sweat glands [66-69]. Skin barrier retards excretion of accumulated toxins, while skin injury disturbs skin excretory functions [70] with retention of drugs and endogenous metabolites [71-73]. Based on that, cupping therapy is so beneficial as it opens skin barrier and enhances skin excretory role.
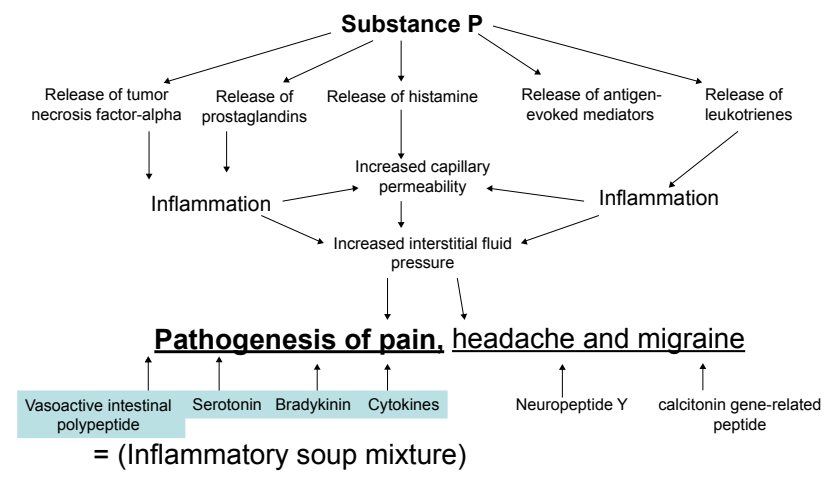

Wet cupping therapy (Al-hijamah) treats pain through dilution and excretion of causative pathological substances including inflammatory soup mixture and neuropeptides, decreasing interstitial fluid pressure, bathing nerve endings in collected fluids to reduce their stimulation, treating predisposing inflammatory factors as trigeminal neuralgia and through release of

Figure 2: Pathogenesis of pain, headache and migraine. Possible role of treatment using wet cupping therapy.

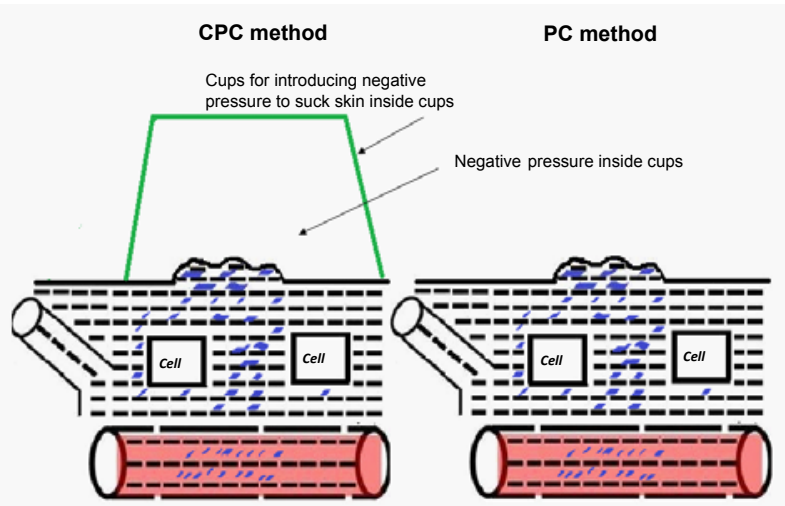

Figure 3A: $1^{\text {st }}$ step ( $1^{\text {st }}$ cupping step) of wet cupping therapy (in the CPC method only not in the PC method). A: Application of cups on skin. 
8- Interstitial fluid is continuously filtered at arterial end of capillaries (net filtration pressure $=-13 \mathrm{~mm} \mathrm{Hg}$ that shifts tissue fluids to the outside of capillaries) [74] and is absorbed at venous end of capillaries (net absorption pressure $=+7 \mathrm{mmHg}$ (Figure 1A) that shifts tissue fluids to the inside of capillaries) 5]. Based on that, external suction pressure (as that occurring in cupping therapy) may enhance the excretion of tissue fluids filled with noxious substances.

\section{B- $1^{\text {st }}$ step of wet cupping therapy $\left(1^{\text {st }}\right.$ cupping $)$}

(In the CPC method only not in the PC method)

1- Skin has a viscoelastic nature, which helps it to be sucked to the inside of cups [75]. When first vacuum pressure is applied during cupping therapy (Figure 3A); negative suction pressure collects

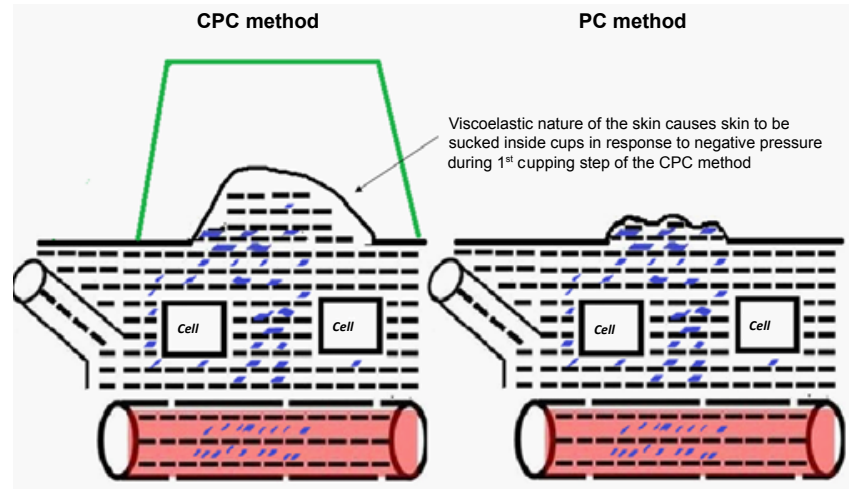

Figure 3B: Skin uplifting starts to form due to viscoelastic nature of the skin and effect of negative pressure suctioning.

CPC method

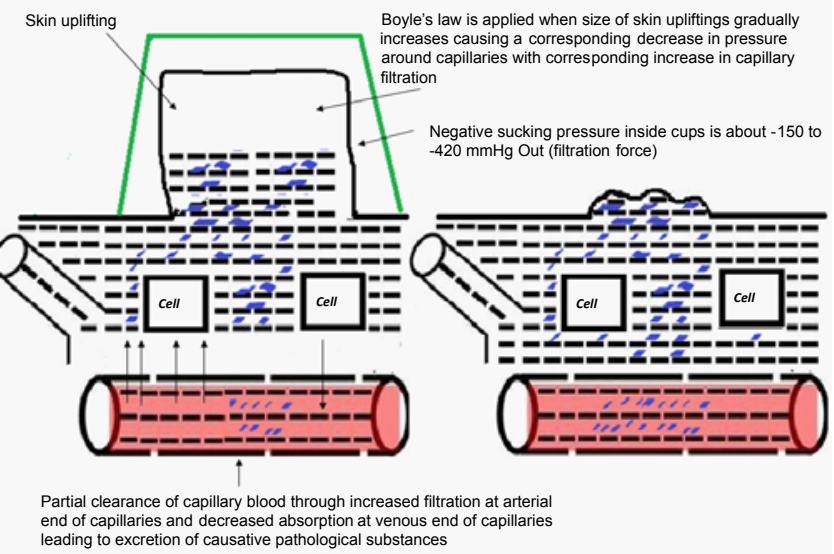

Figure 3C: Skin uplifting progressively increases in size due to viscoelastic nature of skin and effect of negative pressure suctioning. Boyle's law (pressure is inversely related to volume) is applied here. Collected fluids inside skin upliftings contain collected interstitial fluids with causative pathological substances, filtered fluids (from blood capillaries) with causative pathological substances, hemolyzed blood cells (hemolysed RBCs, WBCs and platelets) and filtered soluble substances. That fluid mixture does not contain intact blood cells as their sizes are much bigger than sizes of pores of skin capillaries and cannot be filtered. The fluid mixture is excreted in next steps. Partial clearance of interstitial spaces from causative pathological substances occurs. Partial clearance of capillary blood occurs through increased filtration at arterial end of capillaries and decreased absorption at venous end of capillaries leading to excretion of causative pathological substances. Compression of the skin by the outline of sucking cups causes skin reactive hyperemia. This will enhance skin circulation in next steps for allowing more blood clearance [ $\mathrm{Q}]$.

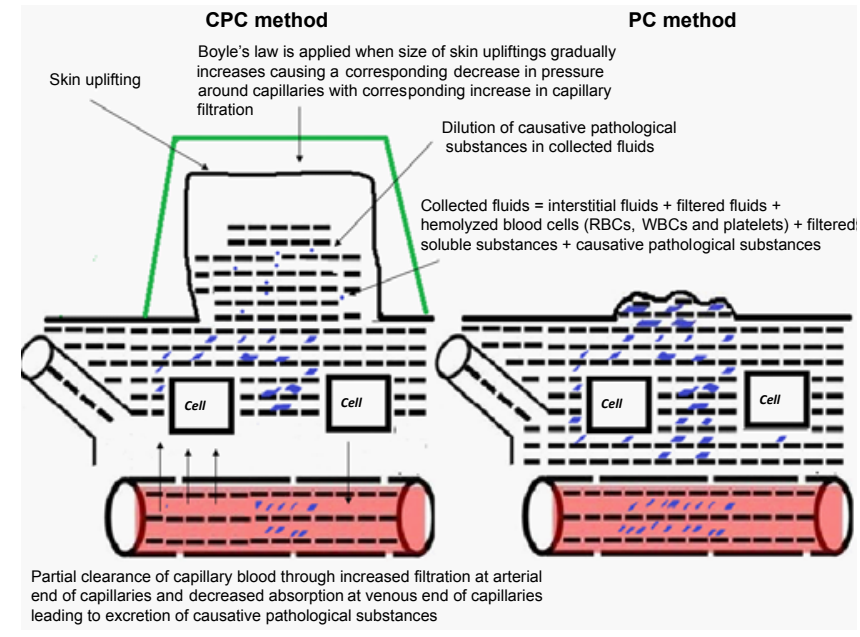

Figure 3D: Skin uplifting progressively increases in size due to viscoelastic nature of skin and effect of negative pressure suctioning. Boyle's law (pressure is inversely related to volume) is applied here. Collected fluids inside skin upliftings contain collected interstitial fluids with causative pathological substances, filtered fluids (from blood capillaries) with causative pathological substances, hemolyzed blood cells (hemolysed RBCs, WBCs and platelets) and filtered soluble substances. That fluid mixture does not contain intact blood cells as their sizes are much bigger than sizes of pores of skin capillaries and cannot be filtered. The fluid mixture is excreted in next steps. Partial clearance of interstitial spaces from causative pathological substances occurs. Partial clearance of capillary blood occurs through increased filtration at arterial end of capillaries and decreased absorption at venous end of capillaries leading to excretion of causative pathological substances. Compression of the skin by the outline of sucking cups causes skin reactive hyperemia. This will enhance skin circulation in next steps for allowing more blood clearance [0]

interstitial fluids in the cupped area causing uplifting of the skin inside cups without any fluid leakage through skin (skin barrier) as intact skin prevents extrusion of tissue fluids (Figure 3B) to outside due to high content of dermal matrix substances (dermatan sulfate, hyaluronic acid and chondroitin sulfate), which constitute the ground substance surrounding the dermal fibrous components that contribute to the viscoelastic nature of the skin. Dermis is strong and elastic due to its high content of elastin protein (makes skin soft and elastic and helps skin sucking inside cups) and collagen protein (gives strength to skin) $[76,77]$. Collected fluids intervene between skin and subcutaneous tissues. This may help breaking connective tissue adhesions. Based on that, skin surface is very suitable for practicing cupping therapy for clearing tissue fluids and capillary fluids.

2- Increase in size of skin uplifting inside cups may decrease local pressure inside skin upliftings around blood capillaries (Boyle's law) [78] leading to filtration of more fluids inside skin upliftings (Figure $3 \mathrm{C})$. Based on that, $1^{\text {st }}$ cupping step in CPC method is very helpful in clearing capillary blood from excess fluids with wastes (via filtration through capillary pores in the local cupped area) as a preparatory step for further capillary blood clearance.

3- With progressive increase in size of skin upliftings, corresponding decrease in pressure occurs inside skin uplifting (Boyle's law) [78] around capillaries leading to more fluid (may contain hemolyzed blood cells but not intact blood cells) filtration from blood capillaries causing more dilution of the inflammatory mediators (Figures 3C and 3D). This may help breaking more connective tissue adhesions with a possible relief of tension muscular spasm. Based on that, all those constitute the scientific rationale of dry cupping therapy.

4- At first, the high negative pressure of cupping therapy sucks more 
skin inside cups causing a more increase in the size of skin upliftings with a corresponding decrease in the pressure inside skin upliftings (till values near that of the capillary venous hydrostatic pressure). This decreases progressively the absorption at the venous end of capillaries (Figures 3C-3E). Movement of filtered fluids towards skin upliftings away from capillaries adds a more decrease to absorption at the venous end of capillaries. Based on that, most of the tissue fluids containing CPS are not absorbed again to venous end of capillary circulation due to effect of cupping therapy.

5- Accumulation of fluids (tissue fluids+filtered fluids+hemolyzed

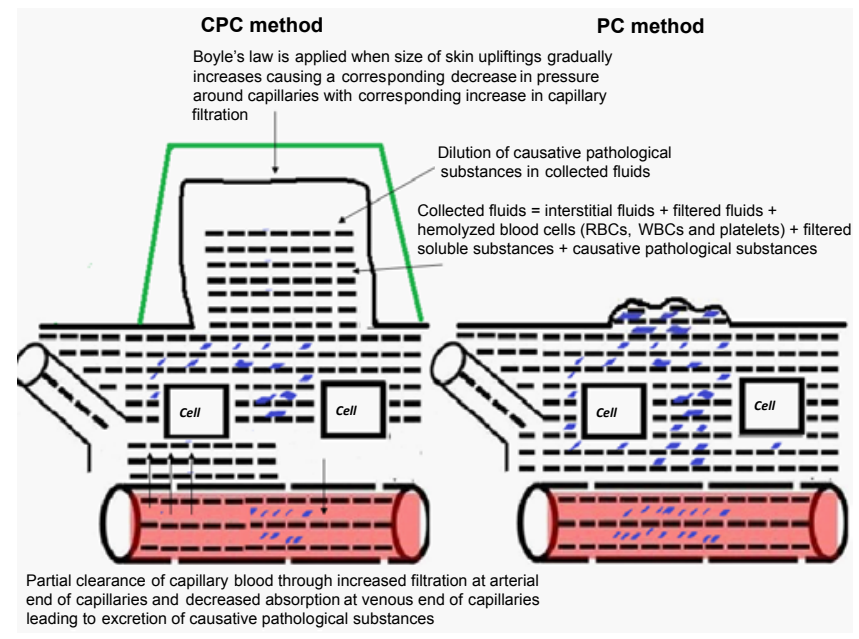

Figure 3E: Skin uplifting progressively increases in size due to viscoelastic nature of skin and effect of negative pressure suctioning. Boyle's law (pressure is inversely related to volume) is applied here. Collected fluids inside skin upliftings contain collected interstitial fluids with causative pathological substances, filtered fluids (from blood capillaries) with causative pathological substances, hemolyzed blood cells (hemolysed RBCs, WBCs and platelets) and filtered soluble substances. That fluid mixture does not contain intact blood cells as their sizes are much bigger than sizes of pores of skin capillaries and cannot be filtered. The fluid mixture is excreted in next steps. Partial clearance of interstitial spaces from causative pathological substances occurs. Partial clearance of capillary blood occurs through increased filtration at arterial end of capillaries and decreased absorption at venous end of capillaries leading to excretion of causative pathological substances. Compression of the skin by the outline of sucking cups causes skin reactive hyperemia. This will enhance skin circulation in next steps for allowing more blood clearance [ㅁ]

CPC method

On removal of sucking cups (negative pressure), a corresponding decrease in negative suction pressure coours leading to decrease in size of skin upliftings to the level of fluids

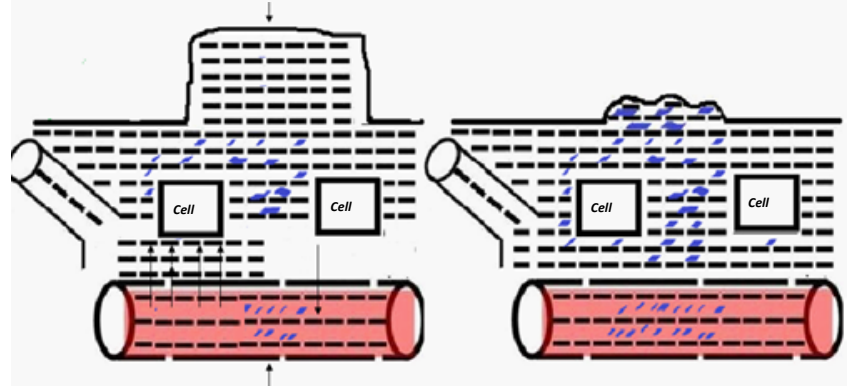

Increased filtration at arterial end of capillaries and decreased absorption at venous end of capillaries leading to continuous of excretion of causative pathological substances

Figure 3F: Removal of sucking cups (negative pressure) causes a decrease in sucking pressure leading to a decrease in size of skin upliftings to the leve of collected fluids. blood cells+filtered soluble substances) containing wastes and hemolyzed blood cells in uplifted cupped skin area may cause dilution and local redistribution of nociceptive mediators (Figures 3C-3E) Nociceptive mediators e.g. substance $\mathrm{P}$ (neuropeptide released from nerve endings and is related to pain), inflammatory mediators and prostaglandins (present in interstitial fluids at local inflammatory sites or come with filtered fluids) are diluted in the locally accumulating tissue fluids in the uplifted area due to the effect of cupping-induced negative suction pressure. This may take substance $\mathrm{P}$ away from pain receptors and pain sensitive structures producing analgesic effect (Figures 2 and 3).

6- Dilution of the inflammatory mediators may occur with temporary accumulation of interstitial fluids and filtered fluids beneath skin surface and around nerve endings (Figures $3 \mathrm{C}-3 \mathrm{E}$ ). This may bathe nerve endings in collected fluids and reduce their stimulation [79]. This may decrease neurotransmission of pain sensation producing an analgesic effect. Analgesic effect of cupping therapy helps in decreasing pain sensation during subsequent superficial skin laceration step. Based on that, $1^{\text {st }}$ cupping step in CPC method (not in PC method) has a strong analgesic effect, which allows doing subsequent skin puncturing with no need for analgesic or anesthetic administration.

7- After removal of sucking cups, immediate decrease in size of skin upliftings occurs due to removal of negative pressure until reaching level of collected fluids (Figure 3F). If skin upliftings are left for some time without skin puncturing (dry cupping therapy), fluid collections inside upliftings will leak and redistribute to underlying tissues causing disappearance of skin upliftings. Improvement of pain instead of retention of inflammatory mediators and noxious substances may be due to dilution of those CPS and their redistribution to new sites away from pain receptors and pain sensitive structures after disappearance of skin upliftings. In addition, skin puncturing allows release of endogenous opioids e.g. endorphins, encephalins and dynorphins that decrease pain sensation [80] and intensify cupping therapy-induced analgesic effect. Derivatives of proopiomelanocortin e.g. $\beta$-endorphin and melanocortin hormones can block inflammatory reactions [80]. Based on that, CPC method of wet cupping therapy is better than dry cupping therapy and PC method in treating pain as CPC method includes 2 advantages: advantage of dry cupping therapy $\left(1^{\text {st }}\right.$ part of the CPC method) and release of endogenous opioids, while PC method has only one advantage through release of endogenous opioids. In the CPC method, better efficient excretion of CPS occurs.

8- Blood capillaries in the cupped area may undergo compression due to pressure on their walls from outside by the accumulated collected fluids. This increases capillary hydrostatic pressure leading to more capillary filtration and consequently more blood clearance. The longer the duration of cupping (for few minutes), the more accumulation of tissue fluid in the skin layers inside the cups (around skin capillaries) until an equilibrium point is reached at which no further fluid will accumulate. Escape and redistribution of fluids from skin uplift back to nearby tissues is prevented by maintained negative pressure during first cupping (for few minutes). Removal of negative pressure of cupping (through removing cups) prevents more accumulation of tissue fluid and instead, allows for slow fluid redistribution. Immediate skin pricking for few millimeters depth is recommended to prevent fluid redistribution and to get better cupping results.

9- Compression pressure exerted on the skin by the outline of sucking cups during the CPC method for few minutes may capture capillary blood in the cupped area (for filtration) and may induce reactive hyperemia phenomenon at the sites of cups application. In 
this phenomenon, compression causes a reduction in blood flow to the skin for few minutes resulting in accumulation of metabolites and vasodilator chemicals. At the end of this step, vascular compression is removed causing a dramatic increase in blood flow to the skin known as reactive hyperemia [38], which may bring more blood to the skin circulation to be filtered and cleared during next steps of Al-hijamah (CPC method).

\section{C- $2^{\text {nd }}$ step of wet cupping therapy (skin puncturing) (In both CPC and PC method)}

1- Injury to skin (as in puncturing step in cupping therapy) causes a double capillary reaction phenomenon. In the first phenomenon, capillary permeability immediately increases for less than 10 minutes (Figure 4). In the second phenomenon, a delayed increase in permeability begins (Figure 4) about one hour after injury [81,82]. Antihistamines affect the first phenomenon but not the second one $[81,82]$. Increased capillary permeability in the first phenomenon is so helpful to enhance capillary filtration, blood clearance of intravascular fluids and fluid collection then movement of collected fluids towards skin puncture site to be excreted under effect of cupping therapy. Practically, this 10 minutes period is consumed in the second cupping step in the CPC method [7] and in creating skin upliftings then cupping

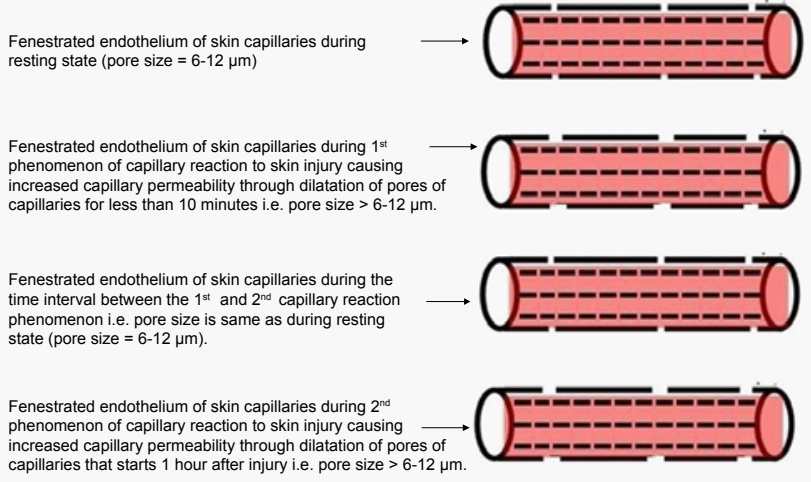

Figure 4: Phenomenon of capillary permeability reaction to trauma $[8 \square, \square 2]$

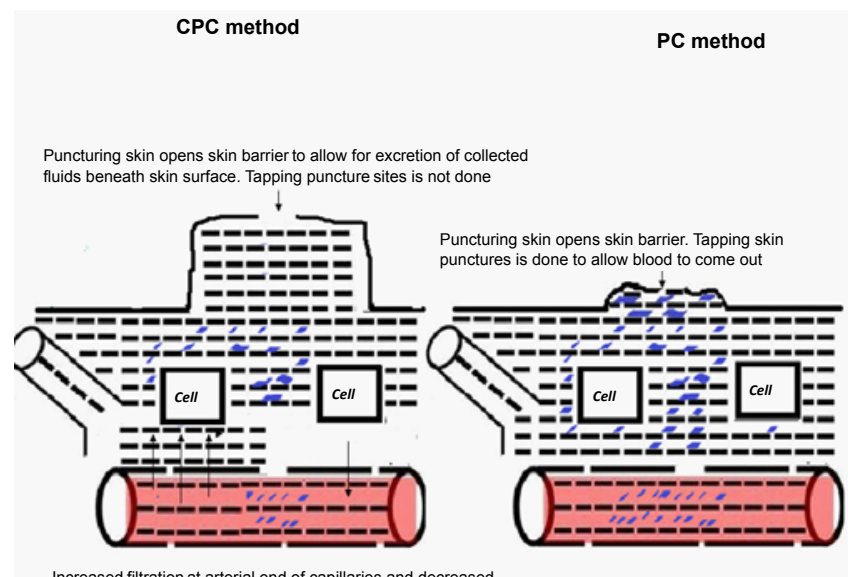

Increased filtration at arterial end of capillaries and decreased excretion of causative pathological substances

Figure 5A: $2^{\text {nd }}$ step of wet cupping therapy (=skin puncturing step) ( $=2^{\text {nd }}$ step in the CPC method and $1^{\text {st }}$ step in the PC method). A: Puncturing skin upliftings in the CPC and PC methods opens skin barrier. Tapping is needed only in the PC method to draw blood out.

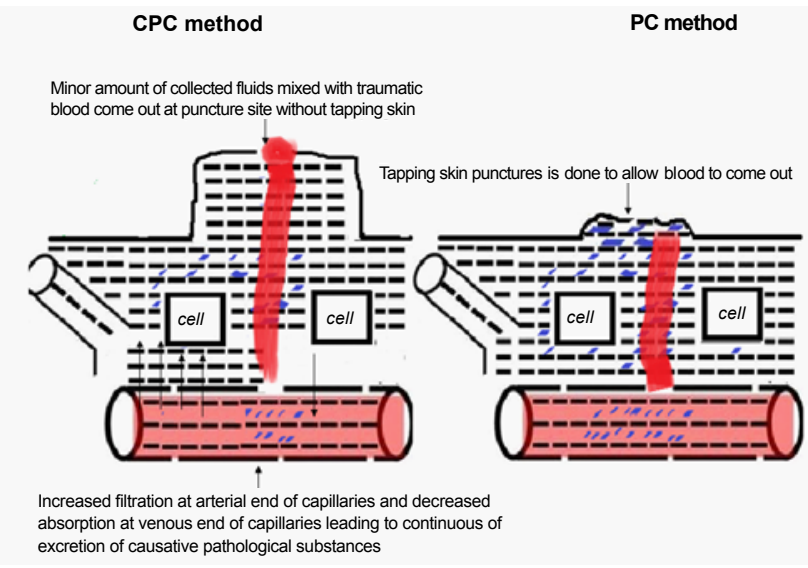

Figure 5B: In the CPC method, collected fluids enhance blood coagulation unlike the PC method, where fresh blood comes out under tapping effect.

step in the PC method [36]. Based on that, CPC method of wet cupping therapy makes better benefit of increased capillary permeability during this 10 minutes period and filters capillary blood during the whole period, while PC method consumes this time to create skin upliftings then to collect fluids. CPC method may be more beneficial in blood clearance than PC method.

2- In the CPC method, collected fluids after first cupping step are retained just beneath skin surface and are ready to get out when skin is punctured (Figure 5A), while nothing is collected in PC method. Injuring skin causes opening of skin barrier and a traumatic injury to capillaries leading to bleeding in both cupping methods.

3- Increased interstitial fluid pressure may cause pain due to nerve compression [83]. Based on that, in the CPC method, puncturing skin is less painful due to collection of fluids (interstitial fluids and filtered fluids) beneath the skin surface leading to decreased interstitial fluid pressure, which decreases pain sensation. In addition, there is dilution and redistribution of the noxious agents, inflammatory mediators and CPS away from pain receptors and pain sensitive structures (Figure 2), while this is not the case in the PC method. In the PC method, pricking skin may be painful at the tender points beneath which pain-causing substances are existing. In addition, localization of inflammation at certain sites produces local erythema and tenderness at these sites, which makes direct skin puncturing painful as in the PC method.

4- In the CPC method, collected fluids are nearer to skin surface than blood in blood capillaries (Figures 5A and 5B). Blood from injured capillaries becomes mixed with collected fluids (interstitial fluids and filtered fluids) beneath skin surface and starts to come out mixed with the collected fluids i.e. altered blood that comes out through superficial skin lacerations induced during wet cupping therapy is a mixture of extruded collected fluids and blood shed at traumatic capillaries. In the PC method, fresh blood comes out rapidly as there is no prior collection of fluids to slow down its flow. Little tissue fluids are mixed with blood, as there is no filtered fluid from capillaries or collected interstitial fluids until this step in the PC method i.e. there is no blood clearance effect until now in the PC method (Figures $5 \mathrm{~A}$ and $5 \mathrm{~B}$ ). The noxious substances that are present in the interstitial fluids are still present and not excreted in the PC method (as noxious substances are not collected or diluted in fluids inside skin uplifting in the PC method).

5- Injury to vessel wall (as that in the puncturing step of cupping therapy) stimulates hemostatic mechanisms of blood coagulation 
(both intrinsic and extrinsic pathways). This leads to vasoconstriction, platelet plug formation (to seal the bleeding site), formation of fibrin thrombus and activation of fibrinolytic system to prevent extension of the thrombus. Damaged endothelial cells releases tissue thromboplastin, which activates the extrinsic pathway of coagulation. Exposure of subendothelial collagen stimulates platelet adhesion and aggregation, activates factor XII (intrinsic pathway of coagulation) and activates fibrinolysis. Platelets soon aggregate to form a platelet plug. In addition, platelets release ADP (increases platelet release reactions), thromboxane A2 (vasoconstrictor), phospholipids (platelet factor 3 that is essential for coagulation) and platelet factor 4 that has a local anti-heparin effect and is essential for coagulation [84]. Based on that, it is essential to start $2^{\text {nd }}$ cupping (suction) step immediately after skin skin puncturing in both CPC and PC methods. In addition, on proper practice of cupping therapy, collected fluids are excreted with minor blood loss.

6- The initiation of coagulation is caused by activation of factor VII through binding of tissue factor (a cell membrane protein). This activates formation of thrombin, which converts soluble fibrinogen to insoluble fibrin threads. Exposed sub-endothelial collagen together with thrombin stimulate platelet aggregation and coagulation cascade [85]. Based on that, proper practice of cupping therapy carries no risk of bleeding or serious hemorrhage.

7- In the CPC method, blood coming up from injured capillaries towards puncture site at the skin surface is facing some collected fluids (Figures 5A and 5B), which may hinder bleeding and enhance coagulation [86]. In PC method, the opposite occurs and blood comes out directly as it does not meet prior collected fluids.

8- Bloodshed during cupping therapy is of capillary origin (based on the superficial nature of skin lacerations during cupping therapy) (Figures 5A and 5B). Depth of skin puncturing in cupping therapy is few millimeters [36] unless a superficial vein is injured (cupping malpractice). Based on that, capillary bloodshed during cupping therapy may help in improving capillary microcirculation, draining metabolic byproducts and relieving degree of congestion in congested capillaries.

\section{D- $3^{\text {rd }}$ step of wet cupping therapy $\left(2^{\text {nd }}\right.$ cupping)}

1- In the CPC method, when second vacuum pressure is applied during cupping therapy (negative suction pressure=suction force), collected fluids are mixed with blood inside skin uplifting then the mixture is sucked to outside the skin. Contact of blood with collected tissue fluids (just beneath skin) surface may slow down the speed of blood flow and may stimulate the coagulation pathway (Figures $5 \mathrm{~A}$ and $5 \mathrm{~B}$ ) and allow time for thrombin formation [86]. Filtered fluids then replace extruded fluids soon in the interstitial spaces then become excreted. In the PC method, application of second vacuum pressure sucks traumatic blood and enhances bleeding as vacuum pressure removes blood rapidly, removes formed clots and hinders thrombus formation. Lack of prior collection of tissue fluids and filtered fluids in the PC method does not slow down the speed of blood flow (Figures 6A-6D). Blood loss in this cupping step may be much more in the PC method than in the CPC method of wet cupping therapy (PC has a high bloodletting effect).

2- In the PC method, puncture sites are usually tapped to draw blood out [6]. In the CPC method, $2^{\text {nd }}$ cupping suctioning is enough to excrete collected fluids inside skin uplifting (no need for tapping puncture sites) (Figures 6A-6D)
3- When second vacuum pressure is applied during cupping therapy, traction forces lead to increased capillary permeability. Observations of Shirley et al. that intravenous infusion of albumin caused capillary distension and increases maximally the porosity of the capillaries led to the conclusion that capillary pores can be stretched i.e. capillary pores are not rigid structures [87]. Based on that, negative pressure suctioning in cupping therapy may stretch capillary pores and enhance fluid filtration and capillary blood clearance especially during the $1^{\text {st }}$ capillary reaction to skin puncturing (about 10 minutes) $[81,82]$.

4- In the CPC method, when second vacuum pressure is applied during cupping therapy; negative suction pressure (suction force and

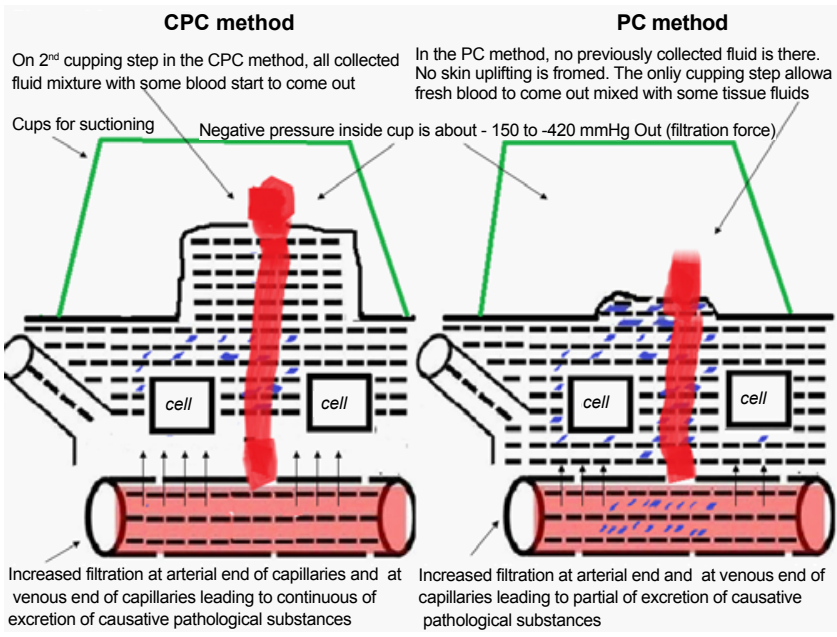

Figure 6A: $3^{\text {rd }}$ step of wet cupping therapy $\left(=2^{\text {nd }}\right.$ cupping step) $\left(=3^{\text {rd }}\right.$ step in the CPC method and $2^{\text {nd }}$ step in the PC method). A: Cupping therapy pressure is a negative pressure force (suction force=filtration force) and was reported to range from ( -200 to $-560 \mathrm{hPa}$, hecta Pascal) [96], which is equivalent to $(-150$ to-420) $\mathrm{mm} \mathrm{Hg}$. In the CPC method, all collected fluid mixture with some blood come out. In the PC method, fresh blood with some tissue fluids comes out. Increased filtration at arterial end of capillaries (exaggeration of normal) and at venous end of capillaries (opposite of normal) occur.

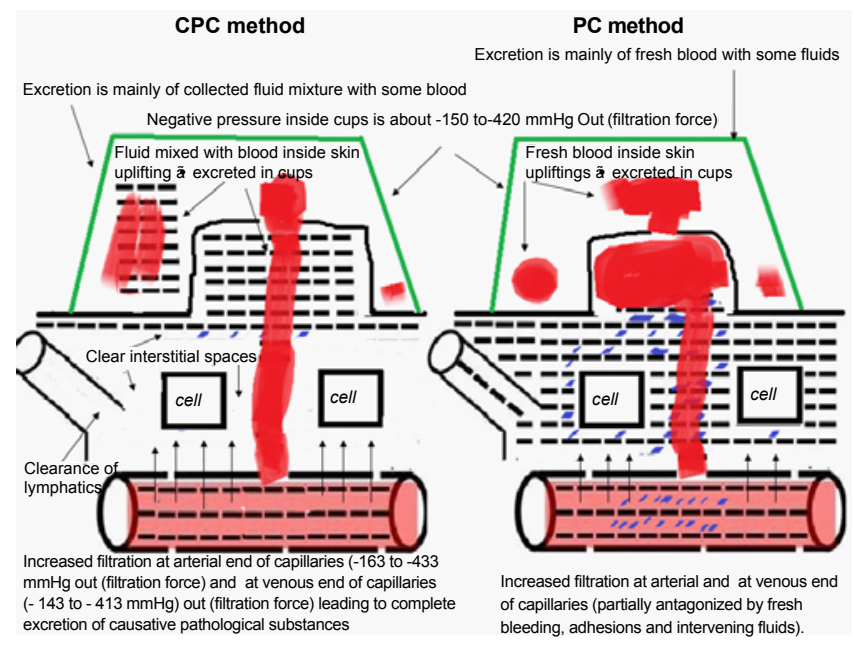

Figure 6B: Skin uplifting of the PC method starts to form in this step and becomes filled with fresh blood mainly. In the CPC method, excretion of collected fluid mixture with some blood occurs. Excretion is mainly of fresh blood with some fluids in the PC method. Clearance of interstitial spaces, lymphatics and blood capillaries occurs more in the CPC method than in the PC method. 


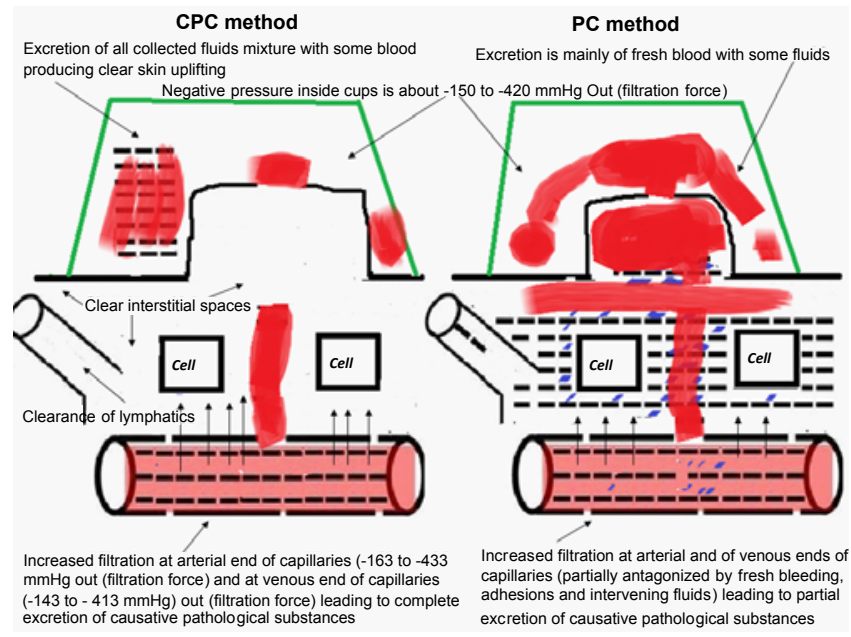

Figure 6C: Skin uplifting of the PC method starts to form in this step and becomes filled with fresh blood mainly. In the CPC method, excretion of collected fluid mixture with some blood occurs. Excretion is mainly of fresh blood with some fluids in the PC method. Clearance of interstitial spaces, lymphatics and blood capillaries occurs more in the CPC method than in the PC method.

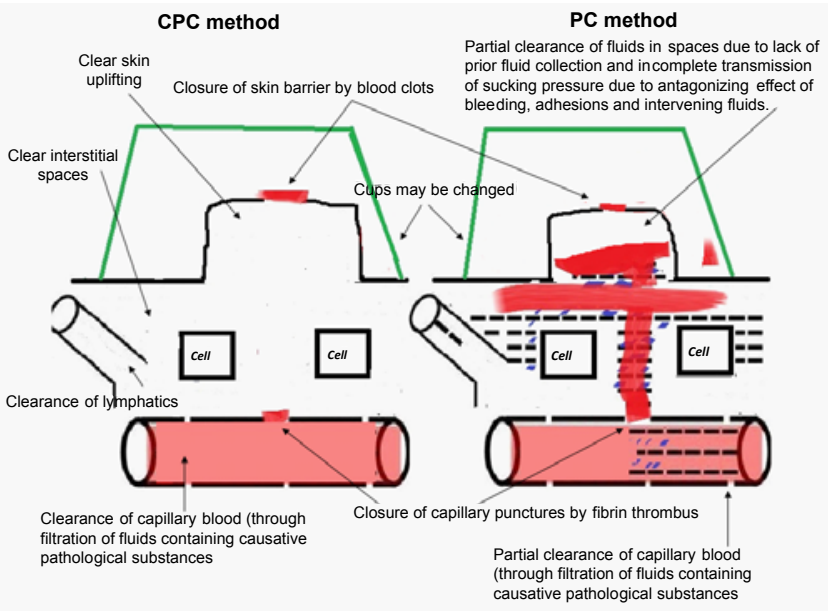

Figure 6D: Clearance is total or near total in the CPC method. In the PC method, partial clearance of interstitial fluids and blood capillaries occurs due to lack of prior fluid collection and incomplete transmission of sucking pressure through skin punctures due to antagonizing effect of bleeding, adhesions and intervening fluids.

filtration force) is transmitted through skin punctures to be added to the capillary hydrostatic pressure (filtration force) leading to increased fluid filtration from intravascular spaces at arterial end of capillaries to interstitial spaces and increased formation of tissue fluids (causing more clearance of blood inside capillaries) that causes more skin uplifting. In the PC method, tissue adhesions, bleeding and interstitial fluids may partially antagonize the transmission of negative pressure from inside cups to around capillaries (Figures 6A-6D). This may decrease filtration force at skin capillaries (decreased blood clearance).

5- In the CPC method, skin uplifting is already formed before puncture step. So, when second vacuum pressure is applied during cupping therapy (for 10 minutes) (Figure 4); continuously filtered fluids (mixed with some traumatic blood) inside skin uplifting is continuously removed (high blood clearance effect) during this whole

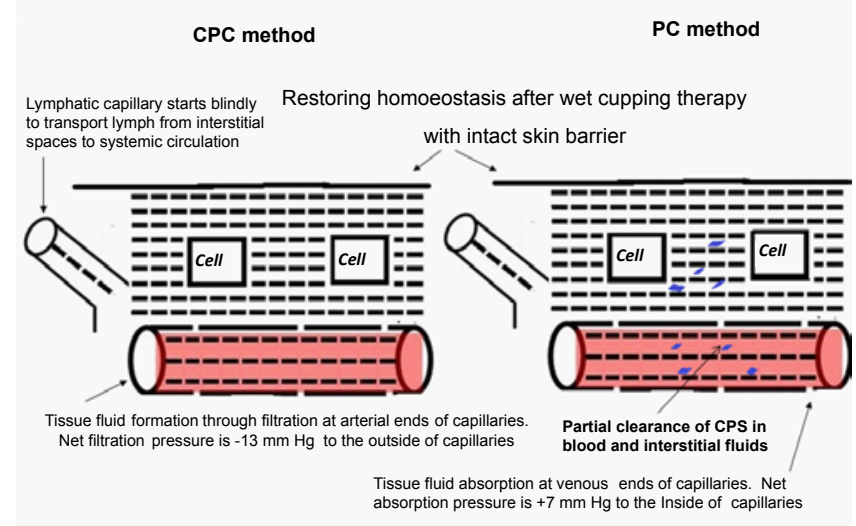

Figure 6E: Restoring homoeostasis after wet cupping therapy with intact skin barrier.

time period (about 10 minutes). Continuous evacuation then filling of the skin upliftings using filtered capillary fluids makes better use of the $1^{\text {st }}$ part of the capillary reaction phenomenon mentioned previously $[81,82]$ in enhancing clearance of capillary fluids. In the PC method, skin upliftings are formed during this step (suction step) and need time to form. Skin upliftings formed in the PC method contain blood, tissue fluids and filtered fluids. Based on that, CPC method clears blood better than the PC method (Figures 6A-6D) as CPC method collects fluids (only fluids without blood) before skin puncturing step and collects fluids (mixed with blood) again after skin puncturing.

6- The last part of cupping step time in the PC method (less than 10 minutes) is consumed in the evacuation of the skin upliftings then filling of the skin upliftings using filtered capillary fluids. This decreases capillary blood clearance effect in the PC method (Figures 6B-6D).

7- In the CPC method, the contents of skin upliftings that are formed before skin puncture step are collected fluids (filtered fluids with soluble substances+interstitial fluids+hemolyzed RBCs+fragmented WBCs+fragmented platelets+CPS) (Figure 3). Intact blood cells (RBCs, WBCs and platelets) are unable to pass through capillary pores. Intact blood cells have sizes in micrometer range [88], which cannot cross pores of fenestrated capillaries of the skin (having sizes in nanometer range, 6-12 nm) [89]. This bathes interstitial spaces with filtered fluids, which take their way towards skin upliftings (Figures 6C and 6D). This helps dilution and redistribution of CPS in collected fluids. After skin puncturing step and sucking fluid inside skin upliftings during $2^{\text {nd }}$ cupping step, new filtered fluids plus blood from traumatized capillaries are collected inside skin upliftings (Figures 6A-6D). In the PC method, fluid collection starts after skin puncture and cupping application to create skin upliftings. This bathes interstitial spaces with fresh traumatic blood, which take its way towards skin upliftings (Figures 6A-6D). Based on that, CPC method induces better clearance effect of tissue spaces and blood capillaries than the PC method.

8- Traction forces exerted on fenestrated capillaries (due to strong persistent negative suction pressure) applied at the skin may increase suction forcibly against their fenestral pore sizes allowing for more filtration of fluid with soluble crystalloid (small particle sizes) and colloid substances (large particle sizes as plasma proteins) e.g. $\beta$-lipoprotein (Molecular weight: 1,300,000) and large molecules can pass through skin capillaries into the tissue fluid $[81,82,90-92]$ then cupping therapy opens skin barrier and enhances natural excretory role of skin. It is worth noting that a large molecule as $\beta$-lipoprotein and globulins 
cannot be filtered through renal glomeruli, as their molecular weight is too large to be filtered. Under physiological conditions, plasma albumin and globulin (high molecular weight proteins) cannot pass through the filtration membrane as their molecular size and negative charge act as barriers that prevent their passage through the glomerular capillary filtration membrane. Opposite to that, low molecular weight proteins as $\beta 2$-microglobulin, a1-microglobulin, and lysozyme can freely pass through the filtration membrane. Majority of these proteins (95\%) are reabsorbed when entering the proximal convoluted tubule although the filtration amount is low [93]. Based on that, cupping therapy facilitates clearing of blood from CPS by increasing skin excretory functions (Figures 6A-6D). This clears blood from more metabolic byproducts, endogenous waste, exogenous toxic materials soluble in interstitial fluids and also clears materials deposited in the interstitial spaces.

9- Cupping therapy pressure is a negative pressure force (suction force $=$ filtration force) and was reported to range from $(-200$ to -560 $\mathrm{hPa}$, hecta Pascal) [94], which is equivalent to $(-150$ to -420$) \mathrm{mmHg}$ (Figures 6A-6D) and drives fluids to move from intravascular compartment to the outside of capillaries). Net filtration pressure at arterial end of capillaries $=-13 \mathrm{mmHg}$ that shifts tissue fluids to the outside of capillaries, while net absorption pressure at venous end of capillaries $=+7 \mathrm{~mm} \mathrm{Hg}$ (Figures $1 \mathrm{~A}$ and $6 \mathrm{E}$ ) that shifts tissue fluids to the inside of capillaries [74]. Based on that, when adding suction pressure of cupping therapy, calculated net filtration pressure at arterial end of capillaries is -163 to $-433 \mathrm{mmHg}$ to the outside of capillaries, while calculated net filtration pressure at venous end of capillaries is -143 to $-413 \mathrm{~mm} \mathrm{Hg}$ to the outside of capillaries (Figures 6B and 6C). Therefore, both capillary ends (arterial end and venous end) filter their fluids due to high-pressure gradient across blood capillaries i.e. (Negative suction pressure+capillary hydrostatic pressure inside blood capillaries $)>$ (osmotic pressure of capillaries at either ends).

10- At first, transmitted high negative pressure of cupping therapy in the CPC method (from inside cups through skin punctures to around skin capillaries) decreases absorption at venous end of capillaries then stops it and finally fluid filtration occurs at venous end of capillaries (opposite of physiological state). More fluid filtration occurs at arterial end of capillaries (exaggeration of physiological state). This is expected to decrease capillary venous return, capillary venous pressure, pressure in larger veins and peripheral vascular resistance. This is also expected to remove blood congestion and enhance blood flow velocity. In the PC method, all that occurs to a lower extent as lower fluid filtration occurs (Figures 3 and 6).

11- Decreased intravascular volume inside blood capillaries in the cupped area (due to fluid filtration and traumatic capillary blood loss) together with the negative suction pressure (induced by cupping) collectively may cause a decrease in hydrostatic pressure inside blood capillaries in cupped area, which may mobilize more blood to local capillaries in the cupped area i.e. enhances capillary microcirculation and circulates more blood for clearance through cupping therapy.

12- Suction of interstitial tissue fluids induced by negative vacuum suction may mobilize interstitial tissue fluids in nearby areas to drain in and refill the interstitial spaces in the cupped area. The continuously applied negative pressure for few minutes in the cupped area may facilitate such mobilization. Drainage of that fluid through cupping lacerations allows continuation of the process and better clearance of stagnant interstitial fluids (Figures 6A-6D).

13- CPC method may be better than the PC method in resolving congested blood. Congested blood is altered in color and contains accumulated cellular waste products, inflammatory mediators and toxins. During the CPC method of wet cupping therapy, congested blood loses its fluids and wastes through filtration. This resolves major part of congestion (Figures 6A-6E). Then, blood comes out immediately after skin puncturing when second cupping step (negative suctioning) is applied to this local area. Its excretion becomes easier (less viscosity) when it is mixed with collected fluids (continuously filtered fluids and tissue fluids). In the PC method, no filtration step occurs before puncturing skin, which does not excrete extra fluids from congested blood. Suction effect stimulates more fresh blood to come from the

\begin{tabular}{|c|c|c|}
\hline Nature & Purpura & Ecchymosis due to cupping therapy \\
\hline & Sign of hematological disease & Mark of doing wet cupping therapy (therapeutic excretory procedure) \\
\hline & Purple discoloration of skin due to cutaneous hemorrhage & $\begin{array}{l}\text { Purple discoloration of skin due to traumatic cutaneous hemorrhage } \\
\text { (cupping pressure-induced trauma) }\end{array}$ \\
\hline Cause & $\begin{array}{l}\text { Thrombocytopenia e.g. idiopathic thrombocytopenic purpura } \\
\text { (ITP), vasculitis, malignancy and others }\end{array}$ & $\begin{array}{l}\text { Suction-induced trauma and passage of fragmented RBCs and platelets } \\
\text { during } 1^{\text {st }} \text { cupping step. In addition, hemorrhage and passage of intact } \\
\text { RBCs and platelets from puncture sites to skin surface in } 2^{\text {nd }} \text { cupping step. }\end{array}$ \\
\hline Treatment & $\begin{array}{l}\text { Treatment of the cause e.g. steroids and platelet transfusion } \\
\text { in ITP. }\end{array}$ & No treatment needed. Purple color is reversible within days to few weeks \\
\hline Blanching on pressure & No blanching & No blanching \\
\hline Site & In hands, legs, back and others & At points of cupping therapy \\
\hline Thrombocytopenia & May be present e.g. in ITP & absent \\
\hline Onset & Acute or chronic & Acute \\
\hline Skin upliftings & Absent & present \\
\hline Course & Disappear after treatment & Disappear without treatment \\
\hline Associated manifestations & Splenomegally or hematuria & None \\
\hline Skin puncture marks & absent & Present \\
\hline Skin level & At skin level & $\begin{array}{l}\text { Margin depressed below skin level, while center is elevated above skin } \\
\text { level and may show remnants of blood }\end{array}$ \\
\hline Size & variable & Same size of cup outline \\
\hline Shape & pleomorphic & Circular (taking shape of cups outline) \\
\hline History of & thrombocytopenia & disease needing cupping therapy \\
\hline Opening of skin barrier & Not done & Done \\
\hline Effect of incising skin & bleeding increases (incising skin is contraindicated) & excretion of contents of skin upliftings \\
\hline Progress & Do not fade with time (unless treated) & Fade with time until disappear \\
\hline
\end{tabular}

Table 4: Differences between purpura and ecchymosis due to Cupping Therapy. 
site of trauma. Lack of previously collected fluids in the PC method allows traumatic blood to move rapidly to outside with little filtered fluids and tissue fluids, while viscosity of congested blood may delay its movement in interstitial spaces in its way to skin puncture site i.e. low blood clearance effect in the PC method.

14- Ecchymosis (large hemorrhagic areas about $2 \mathrm{~cm}$ in diameter causing purple discoloration, which do not blanch on pressure) [95] occurs after cupping therapy and is traumatic in origin and not due to thrombocytopenia. It is different from ecchymosis occurring in thrombocytopenia (Table 4). Bathing the interstitial spaces and the inside of skin upliftings with blood, (more in the PC method than in the CPC method) is the main cause of this ecchymosis.

15- In the CPC method of wet cupping therapy, waste products to be drained in lymphatic capillaries (in addition to some amount of lymph) may be a constituent of the fluid that will be drained through skin incisions to outside under effect of suction pressure. This removes difficulties in lymphatic drainage and improves lymphatic circulation. In the PC method, collected fluids may be lower as skin upliftings form late in the PC method (Figures 6A-6D).

16- Suction of interstitial tissue fluids induced by continuous negative vacuum suction may increase capillary permeability (due to traction forces induced by suction) and may filter more fluids (containing crystalloids and colloids at both arterial and venous ends of capillaries) from blood capillaries to the interstitial spaces. Emptying interstitial spaces due to negative pressure of cupping therapy stimulates more filtration of capillary blood leading to more blood clearance. Continuous excretion through skin lacerations in cupped area allows this process to continue leading to blood clearance (Figure 6D). In the CPC method, a mixture of blood and collected fluids are escaping at the same time at the incision points, which may have a squeezing effect upon traumatized capillaries at the points of traumatic punctures. In the PC method, tissue fluid accumulation occurs slowly, while opened capillaries are bleeding and the amount of bleeding increases by the effect of negative pressure.

17- Cupping-induced increase in capillary blood flow may stimulate more blood flow to cupped area causing more fluid filtration then excretion through skin incisions. This may help improving the systemic and local circulations, improving tissue perfusion, improving cellular oxygenation, improving venous drainage and improving blood clearance.

18- Haemostatic mechanisms (in intact blood vascular system) tend to stop bleeding at injured sites in the cupped area within about 4-8 minutes (normal bleeding time) that ends before session of cupping suction finishes (average 10 minutes). This may minimize blood loss and may allow better filtration and drainage of tissue fluids. Based on that, in the CPC method, blood coagulation may occur earlier than that in the PC method as contact of blood with tissue fluids facilitates coagulation [86]. This occurs in the CPC method. Also, closure of skin barrier due to formation of blood clots at skin puncture sites (at end of bleeding time) is a mechanical termination of wet cupping therapy at which no further excretion occurs and stopping $2^{\text {nd }}$ cupping step should be done (Figure 6D).

\section{E- After the end of cupping therapy}

1- Removal of the CPS and blood congestion may immediately clear the underlying cause of local inflammation, tenderness and pain (similar to medical principle of abscess evacuation). This may improve the underlying muscle contraction without painful spasm. All that may explain cupping-induced analgesia. Drainage of congested blood improves local blood circulation and lymphatic circulation in this area (Figure 6E).

2- Drainage of interstitial fluids and filtered fluids through skin lacerations removes them and decreases absorption of these fluids and their wastes through venous end of capillaries.

3- After finishing session of cupping therapy, new clear tissue fluid gradually forms by filtration of capillary fluids (Figure 6E).

4- Enhancement of lymphatic circulation occurs due to lymph drainage into larger lymph vessels and prevention of flow reversal due to the presence of lymphatic valves.

5- Excretion via wet cupping therapy is multifactorial in origin. It is selective for small particles having sizes less than or equal to capillary fenestral sizes taking into account also pressure factor, time factor and number of cups used for cupping therapy i.e. size-dependent, pressuredependent and time-dependent.

6-Ecchymosis disappears within few days and all side effects of cupping are reversible $[96,97]$.

7-Clearance efficiency of blood and interstitial fluids is better after practicing the CPC method than after practicing the PC method (Figure 6E).

Prophetic Medicine Recommends CPC Method of Wet Cupping Therapy (Al-Hijamah)

The pioneering review article by Loukas et al. recently reported that knowledge gained from religious texts (Qur'an and Hadeeth) is in line with modern medical knowledge. In Islam, Qur'an is the direct spoken words of God, while Hadeeth is the spoken words of Prophet Mohammad peace be upon him [17]

Prophetic medicine is a term given to all the sayings (hadeeth), advices, habits and teachings of Prophet Mohammad peace be upon him as regard health and dealing with diseases. It was reported that in prophetic medicine, cupping therapy is a highly recommended line of treatment in more than one hadeeth: "The best remedy is Al-hijamah (CPC method of wet cupping therapy)" $[18,98,99]$ and: "If there is a benefit in any of your treatment modalities: benefit will be in the blade puncture in cupping therapy, a gulp of honey and cauterizing, but I do not like cauterization" $[17,18]$.

Prophet Mohammad peace be upon him was not a medical practitioner but a great teacher and a guide to his companions and his nation. His advices and teachings were in all aspects of life including health and medical aspects [100]. It was reported that the steps of wet cupping therapy in prophetic era (more than 1400 years ago) were the same steps of the CPC method (not the PC method), where prophet Mohammad peace be upon him requested for wet cupping therapy (Al-hijamah) then the physician started by putting horns (equivalent to sucking cups) for $1^{\text {st }}$ cupping step then he punctured the skin using a lancet then $2^{\text {nd }}$ cupping step was done. A man asked the prophet peace peace be upon him about that procedure. The prophet peace be upon him replied "This is Al-hijamah (wet cupping therapy)". The man asked: "What is Al-hijamah?" The prophet answered:" It is one of the best remedies used by people" [101].

Interestingly, many examples support the conclusion that teachings and advices of Prophet Mohammad peace be upon him agree with the current modern concepts in medicine and health. Among the advices 
is keeping food intake at the minimum and to avoid filling the stomach with food to allow for the ease of drinking and taking a breath: (A human never fills a bottle worse than his stomach. It is enough for man to get a little amount of food to support his stature but if he has to eat, he should fill one third of his stomach with food, one third with water and the last third kept empty to allow for easy respiration) [102]. Keeping one third of stomach empty after food intake gives comfortable sensation as it allows free movement of diaphragm (main respiratory muscle) up and down helping better respiratory act $[103,104]$. This prophetic advice seems enough to regulate nutritional habits and decrease food intake to a minimum, which may be sufficient to prevent occurrence of obesity and its sequelae, e.g. diabetes mellitus, hyperlipidemia, atherosclerosis, hypertension, stroke etc.

In the same context, the prophet peace be upon him practiced intermittent fasting and invited his nation to practice it through keeping abstinence from food for 12-14 hours twice per week in addition to the around 12 hours daily fasting for one month during the month of Ramadan. This proved recently to carry many health benefits e.g. intermittent fasting attenuates proinflammatory cytokines and immune cells in healthy subjects [105], decreases seizure frequency [106] and is effective for weight reduction and cardioprotection [107].

In the same context, it is advisable in prophetic medicine to undergo wet cupping therapy before eating. Prophet Mohammad peace be upon him said: "Al-hijamah before eating is better and gives cure and blessings and increases mental power and memory" [108]. From this hadeeth, valuable scientific facts can be gained which agree with modern medical knowledge. Performing cupping therapy while the stomach is empty will guarantee that the major portion of circulatory blood will not be shifted to gastrointestinal tract (GIT), which guarantees that blood circulation in the skin will not decrease. During food digestion, blood supply to the GIT takes the major portion of blood supply at the expense of skin circulation. Therefore, empty stomach will allow enormous blood to come to the skin circulation to be filtered during cupping therapy. This supports the modern conclusion that cupping therapy filters circulatory blood through filtering blood circulating in skin capillaries. Within 5 minutes of the end of the meal, the superior mesenteric blood flow (upper GIT blood supply) increases by $60 \%$ and the increase reaches about $113 \%$ one hour after the meal [109]. Therefore, after meals, redistribution of blood occurs because of shifting of large amounts of blood into GIT at the expense of other tissues as the skin [110].

In another hadeeth: (If there is a benefit in any of your treatment modalities: benefit will be in the blade puncture in cupping therapy, a gulp of honey and cauterizing, but I do not like cauterization) [18]. The accuracy of using the term (blade puncture in cupping therapy) comes from the fact that in the CPC method of wet cupping (prophetic method of cupping therapy), tissue fluids are accumulating inside skin uplifts with progressive accumulation of tissue fluids and increase in the pressure of fluids inside the skin upliftings. Blade of scalpel is the main step in breaking the skin barrier to allow for excretion of wastes, chemicals, drugs and CPS together with interstitial fluid that will start to be excreted immediately as soon as the blade induces skin punctures. Also, the term "the blade puncture in cupping therapy" seems so precise as the skin puncture sites will be the pathway through which negative pressure of cupping therapy enters the skin and reaches around skin capillaries to create a pressure gradient to filter capillaries leading to excretion of excess fluids containing CPS and then the pressure gradient across the skin will excrete the filtered fluids. Autobiography of prophet Mohammad peace be upon him confirmed using wet cupping therapy for treatment of migraine headache [111]. This agrees with modern medical concepts. Migraine and headache can be treated by wet cupping therapy $[13,25]$ and this can be explained in agreement with recent medical hypotheses e.g. Taibah theory, where cupping therapy induces plasma clearance effect through capillary filtration to remove CPS causing headache. These may include neuropeptides causing headache, excess fluids with metabolic wastes, inflammatory mediators, prostglandins and vasoactive substances. In addition to that, cupping therapy decreases interstitial fluid pressure and corrects predisposing factors for headache e.g. hypertension $[1,21,22]$ and acute trigeminal neuralgia [27]. It is worth noting that neuropeptides are chemical substances, which may be implicated in causing headache e.g. substance P, calcitonin gene-related peptide (CGRP) [112] and vasoactive intestinal polypeptide (VIP) that are important mediators in the pathogenesis of migraine and other primary headaches (Figure 2). Concentrations of CGRP and VIP were reported to be increased in jugular venous plasma during attacks of cluster headache and migraine [113]. Clearance of plasma and blood during wet cupping therapy may explain improvement of headache on treating patients with wet cupping therapy (Figure 2).

In another hadeeth, Prophet Mohammad peace be upon him said: (If tension of blood increases (manifested by hyperemia), one should get wet cupping therapy because severe increase in blood tension may be fatal) [114].

The scientific description mentioned in the hadeeth agrees with current medical knowledge where hypertension may manifest with hyperemia [115]. The use of wet cupping therapy in treatment of severe hypertension may be beneficial as cupping therapy may drain excess fluids with their possible contents of solutes, vasoactive substances, toxins and excess blood (in polycythemia). Hypertension causes increased capillary hydrostatic pressure and increases the filtration of fluids [115]. Cupping therapy may decrease high blood pressure through opening the skin barrier allowing for drainage of excess fluids containing CPS. In this respect, cupping therapy may be better than diuretics as diuretics may cause electrolyte disturbances e.g. hypokalemia [116] caused by loop diuretics and thiazide diuretics, while cupping therapy does not.

\section{Conclusions}

Cupping therapy is based on solid medical bases and its history is a contribution of human civilizations. Cupping therapy does not equal only bleeding or bloodletting. Instead of that, cupping therapy filters and clears capillary blood and interstitial fluids.

Wet cupping therapy is better than dry cupping therapy as it excretes CPS to restore physiology, while dry cupping therapy depends on dilution and redistribution of CPS to new sites.

CPC method of wet cupping therapy was reported early in prophetic medicine and it is the only practiced method of wet cupping therapy since prophetic era until now in Saudi Arabia and other Islamic countries. CPC method of wet cupping therapy is also called Al-hijamah, which is different in methodology and outcome from the PC method that is reported in other research studies. Based on that, when analyzing research data of wet cupping therapy, researchers should be alert when analyzing data and should ask clearly: what type of wet cupping therapy was done? Al-hijamah (CPC method) or the PC method? It is not accepted to mix data results of the CPC method with data results of the PC method.

Puncturing skin induces a capillary reaction in which permeability 
Citation: El Sayed SM, Mahmoud HS, Nabo MMH (2013) Methods of Wet Cupping Therapy (Al-Hijamah): In Light of Modern Medicine and Prophetic Medicine. Altern Integ Med 2: 111. doi:10.4172/2327-5162.1000111

Page 14 of 16

increases for less than 10 minutes, which may be helpful to enhance blood clearance in cupping therapy.

CPC method seems to be better than the PC method of wet cupping therapy as regard blood and interstitial fluid clearing effect and analgesic effect.

In the PC method of wet cupping, puncturing skin seems to be painful as in pricking with lancets. Blood (but not interstitial fluid) is getting out from puncture sites. PC method-derived cupped fluid contains more blood and less tissue fluid (less effective in cleansing tissue spaces and clearing blood). PC method seems to cause an increased bleeding until hemostasis.

In the CPC method of wet cupping, uplifting of the skin inside the cup allows for better collection of interstitial fluids and filtered fluids than in the PC method leading to separation of the skin, subcutaneous tissues and underlying tissue layers temporarily and breaking tissue adhesions. This collects fluids from nearby areas to the cupped area and prevents their escape because of the skin barrier. Skin puncturing allows for the escape of collected fluids through skin puncture sites. Bleeding at points of capillary trauma may take place as skin is richly supplied by capillary networks. Cupping after skin puncturing drains collected fluids in the cupped area with blood from injured capillaries until hemostasis occurs. Contact of blood with tissue fluids stimulates pathways of coagulation, which decrease blood loss in the CPC method (blood loss is more in the PC method).

Scientific facts in modern medicine agree with knowledge gained from prophetic medicine. This is true when comparing the harmony of prophetic teachings with modern medical concepts e.g. in intermittent fasting, nutrition, cupping therapy and others. We recommend further future research and scientific analysis of remedies and preventive aspects in prophetic medicine.

It is strongly recommended to recognize wet cupping therapy especially CPC method (Al-hijamah) and allow its practice officially in hospitals for the great benefit it exerts in clearing blood and interstitial fluids from CPS and restoring physiological homeostasis.

\section{Future Perspectives}

Unfortunately, modern medicine in North America and Europe, with some exceptions, does not pay enough attention to cupping therapy to the extent that cupping therapy is not recognized officially in many developed countries. Scientific research is not directed enough to this economic, easy and effective line of treatment. When benefits of cupping therapy are discussed, many physicians have no idea about it. The way cupping therapy is presented to medical practitioners is not scientific and does not explain scientific mechanisms underlying wet cupping therapy. That urged us to try to explain how cupping therapy works from the scientific and medical point of view.

The future of cupping therapy seems promising despite all previously mentioned obstacles for many reasons: the bad need of human diseases to new more effective lines of treatment due to treatment failure in many disease conditions. Simplicity of cupping therapy, being economic, being safe with good success results in many patients and having promising initial research results in favor of cupping therapy for a large panel of diseases. Finally, better scientific understanding of the mechanism of action cupping therapy seems promising for worldwide recognition of cupping therapy.

\section{Acknowledgements}

We are so grateful to the library of Sohag faculty of medicine, Sohag University,
Egypt for providing the internet facility and helpful textbooks.

The authors declare that there is no conflict of interest.

\section{References}

1. AL- Shamma YM, Abdil Razzaq A (2009) Al-Hijamah Cupping Therapy. Kufa Med J 12 (1).

2. Chirali IZ (1999) The cupping procedure. In: Chirali IZ (1999) Traditional Chinese Medicine Cupping Therapy. London: Churchill Livingstone 73-86.

3. Cao H, Li X, Liu J (2012) An updated review of the efficacy of cupping therapy. PLoS One 7: e31793.

4. Michalsen A, Bock S, Lüdtke R, Rampp T, Baecker M, et al. (2009) Effects of traditional cupping therapy in patients with carpal tunnel syndrome: a randomized controlled trial. J Pain 10: 601-608.

5. Salomonsen LJ, Skovgaard L, la Cour S, Nyborg L, Launsø L, et al. (2011) Use of complementary and alternative medicine at Norwegian and Danish hospitals. BMC Complement Altern Med 11: 4.

6. Cao H, Liu J, Lewith GT (2010) Traditional Chinese Medicine for treatment of fibromyalgia: a systematic review of randomized controlled trials. J Altern Complement Med 16: 397-409.

7. Shaheed Abd Hameed Omar (2009) Al-hijamah (cupping therapy): Sunnah and therapy (in Arabic). Dar Ommah for publication, Jeddah.

8. McMullin MF, Bareford D, Campbell P, Green AR, Harrison C, et al. (2005) Guidelines for the diagnosis, investigation and management of polycythaemia/ erythrocytosis. Br J Haematol 130: 174-195.

9. Christopoulou-Aletra H, Papavramidou N (2008) Cupping: an alternative surgical procedure used by Hippocratic physicians. J Altern Complement Med 14: 899-902.

10. Teut M, Kaiser S, Ortiz M, Roll S, Binting S, et al. (2012) Pulsatile dry cupping in patients with osteoarthritis of the knee - a randomized controlled exploratory trial. BMC Complement Altern Med 12: 184

11. Turk JL, Allen E (1983) Bleeding and cupping. Ann R Coll Surg Engl 65: 128131.

12. Abele J Das Schröpfen (1996) Eine bewährte alternative Heilmethode Taschenbuch: Urban \& Fischer, Mchn.

13. Ahmadi A, Schwebel DC, Rezaei M (2008) The efficacy of wet-cupping in the treatment of tension and migraine headache. Am J Chin Med 36: 37-44.

14. Eisenberg DM, Davis RB, Ettner SL, Appel S, Wilkey S, et al. (1998) Trends in alternative medicine use in the United States, 1990-1997: results of a follow-up national survey. JAMA 280: 1569-1575.

15. Kemper KJ, Sarah R, Silver-Highfield E, Xiarhos E, Barnes L, et al. (2000) On pins and needles? Pediatric pain patients' experience with acupuncture. Pediatrics 105: 941-947.

16. Kim TH, Basargard L, Kim JI, Lee MS (2011) Mongolian traditional style bloodletting therapy: a brief introduction. Complement Ther Clin Pract 17: 179-183.

17. Loukas M, Saad Y, Tubbs RS, Shoja MM (2010) The heart and cardiovascular system in the Qur'an and Hadeeth. Int J Cardiol 140: 19-23.

18. Al-Bukhari MI (1996) The English Translation of Sahih Al Bukhari With the Arabic Text. Translated by Muhammad Muhsin Khan, Al-Saadawi Publications 9.

19. Cao H, Zhu C, Liu J (2010) Wet cupping therapy for treatment of herpes zoster: a systematic review of randomized controlled trials. Altern Ther Health Med 16: $48-54$

20. Awad SS (2008) Chinese cupping: a simple method to obtain epithelial grafts for the management of resistant localized vitiligo. Dermatol Surg 34: 1186-1192.

21. Hänninen O, Vaskilampi T (1982) Cupping as a part of living finnish traditional healing. A remedy against pain. Acupunct Electrother Res 7: 39-50.

22. Lee MS, Kim Jl, Ernst E (2011) Is cupping an effective treatment? An overview of systematic reviews. J Acupunct Meridian Stud 4: 1-4.

23. Ahmed SM, Madbouly NH, Maklad SS, Abu-Shady EA(2005) Immunomodulatory effects of blood letting cupping therapy in patients with rheumatoid arthritis Egypt J Immunol 12: 39-51. 
Citation: El Sayed SM, Mahmoud HS, Nabo MMH (2013) Methods of Wet Cupping Therapy (Al-Hijamah): In Light of Modern Medicine and Prophetic Medicine. Altern Integ Med 2: 111. doi:10.4172/2327-5162.1000111

24. Hssanien MM, Mansoura Fawaz S, Ahmed AF, Al Emadi S, Hammoudeh M (2010) Effect of cupping therapy in treating chronic headache and chronic back pain at "Al heijamah" clinic HMC. World Family Medicine Journal 8 (3).

25. Koehler PJ, Boes CJ (2010) A history of non-drug treatment in headache, particularly migraine. Brain 133: 2489-2500.

26. Sultana A, Ur Rahman K, Farzana M, Lone A (2010) Efficacy of hijamat bila shurt (dry cupping) on intensity of pain in dysmenorrhoea-a preliminary study. Anc Sci Life 30: 47-50.

27. Zhang Z (1997) Observation on therapeutic effects of blood-letting puncture with cupping in acute trigeminal neuralgia. J Tradit Chin Med 17: 272-274.

28. Zhang HL (2009) Blood-letting puncture and cupping therapies combined with acupuncture for treatment of 140 cases of fibrositis. J Tradit Chin Med 29: 277 278.

29. Cao H, Hu H, Colagiuri B, Liu J (2011) Medicinal cupping therapy in 30 patients with fibromyalgia: a case series observation. Forsch Komplementmed 18: 122 126.

30. Li CD, Fu XY, Jiang ZY, Yang XG, Huang SQ, et al. (2006) Clinical study on combination of acupuncture, cupping and medicine for treatment of fibromyalgia syndrome. Zhongguo Zhen Jiu 26: 8-10.

31. Jang ZY, Li CD, Qiu L, Guo JH, He LN, et al. (2010) Combination of acupuncture cupping and medicine for treatment of fibromyalgia syndrome: a multi-centra randomized controlled trial. Zhongguo Zhen Jiu 30: 265-269.

32. Lüdtke R, Albrecht U, Stange R, Uehleke B (2006) Brachialgia paraesthetica nocturna can be relieved by "wet cupping"--results of a randomised pilot study. Complement Ther Med 14: 247-253.

33. Lauche R, Cramer H, Choi KE, Rampp T, Saha FJ, et al. (2011) The influence of a series of five dry cupping treatments on pain and mechanical thresholds in patients with chronic non-specific neck pain--a randomised controlled pilot study. BMC Complement Altern Med 11: 63.

34. Lauche R, Cramer H, Hohmann C, Choi KE, Rampp T, et al. (2012) The effect of traditional cupping on pain and mechanical thresholds in patients with chronic nonspecific neck pain: a randomised controlled pilot study. Evid Based Complement Alternat Med 2012: 429718.

35. Lauche R, Cramer H, Haller H, Musial F, Langhorst J, et al. (2012) My back has shrunk: the influence of traditional cupping on body image in patients with chronic non-specific neck pain. Forsch Komplementmed 19: 68-74.

36. Kim JI, Kim TH, Lee MS, Kang JW, Kim KH, et al. (2011) Evaluation of wetcupping therapy for persistent non-specific low back pain: a randomised waiting-list controlled, open-label, parallel-group pilot trial. Trials 12: 146.

37. Zhang SJ, Liu JP, He KQ (2010) Treatment of acute gouty arthritis by bloodletting cupping plus herbal medicine. J Tradit Chin Med 30: 18-20.

38. Saladin KS (2003) Anatomy \& Physiology: The Unity of Form and Function In: The microcirculation and the lymphatic system (3 $3^{\text {rd }}$ edition) The McGrawHillcompanies 262.

39. Hany Salah Mahmoud (2013) Scientific and practical bases of the prophetic miracle, Al-hijamah ( $1^{\text {st }}$ edn) Dar Al Afany for press, Cairo, Egypt 102-107.

40. Kim TH, Kang JW, Kim KH, Lee MH, Kim JE, et al. (2012) Cupping for treating neck pain in video display terminal (VDT) users: a randomized controlled pilot trial. J Occup Health 54: 416-426.

41. Mohamed Ahmed Easa (2005) Therapy using hijama and air cups ( $1^{\text {st }}$ edn) Dar Al Ghadd Al-Gadid, Egypt almansoura 61.

42. Huang YL (2008) Cupping-bloodletting therapy of Saudi Arabia and its clinical application. Zhongguo Zhen Jiu 28: 375-377.

43. Shekarforoush S, Foadoddini M (2012) Cardiac effects of cupping: myocardial infarction, arrhythmias, heart rate and mean arterial blood pressure in the rat heart. Chin J Physiol 55: 253-258.

44. Al-Rubaye KQ (2012) The clinical and histological skin changes after the cupping therapy (Al-hijamah). J Turk Acad Dermatol 6: 1261a1.

45. Bilal M, Khan RA, Ahmed A, Afroz A (2011) Partial evaluation of technique used in cupping therapy. Journal of Basic and Applied Sciences 7: 65-68.

46. Scallan J, Huxley VH, Korthuis RJ (2010) Capillary Fluid Exchange: Regulation Functions, and Pathology. In: The Interstitium. San Rafael (CA): Morgan \& Claypool Life Sciences.
47. Scallan J, Huxley VH, Korthuis RJ (2010) Capillary Fluid Exchange Regulation, Functions, and Pathology. In: Integrated Systems Physiology: from Molecule to Function to Disease. University of Missouri-Columbia San Rafael (CA): Morgan \& Claypool Life Sciences.

48. Skrzycki M, Czeczot H (2004) [Extracellular superoxide dismutase (EC-SOD)-structure, properties and functions]. Postepy Hig Med Dosw (Online) 58: 301 311.

49. Yuan SY, Rigor RR (2010) Regulation of Endothelial Barrier Function. In: Structure and Function of Exchange Microvessels. San Rafael (CA): Morgan \& Claypool Life Sciences.

50. Brezinschek HP (2008) Mechanisms of muscle pain : significance of trigger points and tender points. Z Rheumatol 67: 653-654, 656-7.

51. McGregor DD, Logie PS (1974) The mediator of cellular immunity. VII. Localization of sensitized lymphocytes in inflammatory exudates. J Exp Med 139: $1415-1430$

52. Safieh-Garabedian B, Kanaan SA, Jabbur SJ, Saadé NE (1999) Cytokinemediated or direct effects of thymulin on the nervous system as assessed by pain-related behavior. Neuroimmunomodulation 6: 39-44.

53. McCabe WR, Treadwell TL, De Maria A Jr (1983) Pathophysiology of bacteremia. Am J Med 75: 7-18.

54. Sloop CH, Dory L, Roheim PS (1987) Interstitial fluid lipoproteins. J Lipid Res 28: $225-237$.

55. Di Sebastiano P, di Mola FF, Buchler MW, Friess H (2004) Pathogenesis of pain in chronic pancreatitis. Dig Dis 22: 267-272.

56. Tamminga CA (2006) Substance P: A Neuropeptide. Am J Psychiatry 163: 4

57. Ebertz JM, Hirshman CA, Kettelkamp NS, Uno H, Hanifin JM (1987) Substance $\mathrm{P}$-induced histamine release in human cutaneous mast cells. J Invest Dermatol 88: $682-685$.

58. Baumgarten CR, Witzel A, Kleine-Tebbe J, Kunkel G (1996) Substance P enhances antigen-evoked mediator release from human nasal mucosa. Peptides 17: 25-30.

59. Okabe T, Hide M, Koro O, Yamamoto S (2000) Substance P induces tumo necrosis factor-alpha release from human skin via mitogen-activated protein kinase. Eur J Pharmacol 398: 309-315.

60. Okabe T, Hide M, Koro O, Nimi N, Yamamoto S (2001) The release of leukotriene B4 from human skin in response to substance $\mathrm{P}$. evidence for the functional heterogeneity of human skin mast cells among individuals. Clin Exp Immunol 124: 150-156

61. Wiig H, Rubin K, Reed RK (2003) New and active role of the interstitium in control of interstitial fluid pressure: potential therapeutic consequences. Acta Anaesthesiol Scand 47: 111-121.

62. Goodwin SA (1998) A review of preemptive analgesia. J Perianesth Nurs 13 109-114.

63. Pannatier A, Jenner P, Testa B, Etter JC (1978) The skin as a drug-metabolizing organ. Drug Metab Rev 8: 319-343.

64. Svensson CK (2009) Biotransformation of drugs in human skin. Drug Metab Dispos 37: 247-253.

65. Korkina L, Pastore S (2009) The role of redox regulation in the normal physiology and inflammatory diseases of skin. Front Biosci (Elite Ed) 1: 123 141.

66. Johnson HL, Maibach HI (1971) Drug excretion in human eccrine sweat. J Invest Dermatol 56: 182-188.

67. Omokhodion FO, Howard JM (1994) Trace elements in the sweat of acclimatized persons. Clin Chim Acta 231: 23-28.

68. Sato K (1977) The physiology, pharmacology, and biochemistry of the eccrine sweat gland. Rev Physiol Biochem Pharmacol 79: 51-131.

69. Stauber JL, Florence TM (1988) A comparative study of copper, lead, cadmium and zinc in human sweat and blood. Sci Total Environ 74: 235-247.

70. Liu XX, Sun CB, Yang TT, Li D, Li CY, et al. (2012) Decreased skin-mediated detoxification contributes to oxidative stress and insulin resistance. Exp Diabetes Res 2012: 128694.

71. Gauglitz GG, Herndon DN, Kulp GA, Meyer WJ 3rd, Jeschke MG (2009) 
Citation: El Sayed SM, Mahmoud HS, Nabo MMH (2013) Methods of Wet Cupping Therapy (Al-Hijamah): In Light of Modern Medicine and Prophetic Medicine. Altern Integ Med 2: 111. doi:10.4172/2327-5162.1000111

Abnormal insulin sensitivity persists up to three years in pediatric patients postburn. J Clin Endocrinol Metab 94: 1656-1664.

72. Jeschke MG, Finnerty CC, Herndon DN, Song J, Boehning D, et al. (2012) Severe injury is associated with insulin resistance, endoplasmic reticulum stress response, and unfolded protein response. Ann Surg 255: 370-378.

73. Jeschke MG, Gauglitz GG, Kulp GA, Finnerty CC, Williams FN, et al. (2011) Long-term persistance of the pathophysiologic response to severe burn injury. PLoS One 6: e21245.

74. Saladin KS (2003) Anatomy \& Physiology: The Unity of Form and Function. In: The circulatory system, blood vessels and circulation (3rdedn) The McGraw-Hill companies 761 .

75. Tham LM, Lee HP, Lu C (2006) Cupping: from a biomechanical perspective. J Biomech 39: 2183-2193.

76. Fawcett DW (1986) A textbook of histology (11thedn) Philadelphia: W.B. Saunders Company.

77. Sanders JE, Goldstein BS, Leotta DF (1995) Skin response to mechanica stress: adaptation rather than breakdown--a review of the literature. J Rehabi Res Dev 32: 214-226.

78. West JB (1999) The original presentation of Boyle's law. J Appl Physiol 87 1543-1545.

79. Emflorgo CA (1999) The assessment and treatment of wound pain. J Wound Care 8: 384-385.

80. Han JS (2004) Acupuncture and endorphins. Neurosci Lett 361: 258-261.

81. SEVITT S (1958) Early and delayed oedema and increase in capillary permeability after burns of the skin. J Pathol Bacteriol 75: 27-37.

82. ASSCHER AW, JONES JH (1965) CAPILLARY PERMEABILITY TO PLASMA PROTEINS. Postgrad Med J 41: 425-434.

83. Shiri R, Heliövaara M, Moilanen L, Viikari J, Liira H, et al. (2011) Associations of cardiovascular risk factors, carotid intima-media thickness and manifest atherosclerotic vascular disease with carpal tunnel syndrome. BMC Musculoskelet Disord 12: 80

84. Magid Ashraf, Mohamed Salah El-Din (2003) Pediatric hematology \& oncology $\left(2^{\text {nd }}\right.$ edn) The scientific book center 35

85. Provan D, Singer RJ, Baglin T, Dokal I (2011) Oxford handbook of clinical hematology ( $3^{\text {rd }}$ edn) Oxford University Press 450-451.

86. Green D, McMahon B, Foiles N, Tian L (2008) Measurement of hemostatic factors in EDTA plasma. Am J Clin Pathol 130: 811-815.

87. SHIRLEY HH Jr, WOLFRAM CG, WASSERMAN K, MAYERSON HS (1957) Capillary permeability to macromolecules: stretched pore phenomenon. Am J Physiol 190: 189-193.

88. Theml H, Diem H, Haferlach T (2002) Color Atlas of Hematology: Practical Microscopic and Clinical Diagnosis. In: Normal Cells of the Blood and Hematopoietic Organs ( $2^{\text {nd }}$ edn) Thieme Verlag, Stuttgart, Germany 29-50.

89. Sarin H (2010) Physiologic upper limits of pore size of different blood capillary types and another perspective on the dual pore theory of microvascular permeability. J Angiogenes Res 2: 14

90. Landis EM, Jonas L, Angevine M, Erb W (1932) THE PASSAGE OF FLUID AND PROTEIN THROUGH THE HUMAN CAPILLARY WALL DURING VENOUS CONGESTION. J Clin Invest 11: 717-734.

91. COURTICE FC (1961) The transfer of proteins and lipids from plasma to lymph in the leg of the normal and hypercholesterolaemic rabbit. J Physiol 155: 456469

92. COURTICE GC, MORRIS B (1955) The exchange of lipids between plasma and lymph of animals. Q J Exp Physiol Cogn Med Sci 40: 138-148.

93. Zhang A, Huang S (2012) Progress in pathogenesis of proteinuria. Int J Nephro 2012: 314251 .

94. Huber R, Emerich M, Braeunig M (2011) Cupping-is it reproducible? Experiments about factors determining the vacuum. Complement Ther Med 19: 78-83.

95. Mohammed El-Naggar (2007) Pediatric clinical diagnosis. In: Purpura. (5th edn) Al-Ahram commercial press, Kalyoub, Egypt 341-347.
96. Wong HC, Wong JK, Wong NY (1999) Signs of physical abuse or evidence of moxibustion, cupping or coining? CMAJ 160: 785-786.

97. Shixi, Huang; Yu, Cao (2006) Cupping therapy. (treatment methods). The Journal of Chinese Medicine.

98. Melfy Ben Hassan (2006) Al-hijama (wet cupping therapy): Science and cure (in Arabic). Dar Al-mohaddeesin for publication, Cairo, Egypt 73.

99. Abo Alfidaa Mohamed Ezzat (2004) Secrets of treatment using Al-hijama (we cupping therapy) and phlebotomy (in Arabic). Dar Al-fadeela for publication, Cairo, Egypt 37.

100. Al-Jauziyah IIQ (1999) Healing with the Medicine of the Prophet (Peace be upon Him). Fordham University: Darussalam Publishers \& Distributors; Translated by Jalal Abual Rub.

101. Ahmed Ben Hanbal (1998) Mosnad Ahmad (in Arabic). Qurtoba foundation fo press. Cairo, Egypt 6: Hadeeth no. 20108

102. Al-Albani M N (2000) Sahih of the small collection. Islamic bureau for publishing. Hadeeth no. 5675

103. Carry PY, Banssillon V (1994) Intra-abdominal pressure. Ann Fr Anesth Reanim 13: 381-399.

104.Druz WS, Sharp JT (1981) Activity of respiratory muscles in upright and recumbent humans. J Appl Physiol 51: 1552-1561.

105. Faris MA, Kacimi S, Al-Kurd RA, Fararjeh MA, Bustanji YK, et al. (2012) Intermittent fasting during Ramadan attenuates proinflammatory cytokines and immune cells in healthy subjects. Nutr Res 32: 947-955.

106. Hartman AL, Rubenstein JE, Kossoff EH (2012) Intermittent fasting: A "new" historical strategy for controlling seizures? Epilepsy Res.

107. Klempel MC, Kroeger CM, Bhutani S, Trepanowski JF, Varady KA (2012) Intermittent fasting combined with calorie restriction is effective for weight loss and cardio-protection in obese women. Nutr J 11: 98.

108. Al-Albani M N (1996) Series of correct hadeeths ( $\left(^{\text {st }}\right.$ edn) Library of knowledge for publication 2: 392

109. Norryd C, Denker H, Lunderquist A, Olin T, Tylén U (1975) Superior mesenteric blood flow during digestion in man. Acta Chir Scand 141: 197-202.

110. Ambarish V, Barde P, Vyas A, Deepak KK (2005) Comparison between pre-prandial and post-prandial heart rate variability (HRV). Indian J Physio Pharmacol 49: 436-442.

111. Al-Bukhari MI (1996) The English Translation of Sahih Al Bukhari With the Arabic Text. Translated by Muhammad Muhsin Khan, Al-Saadawi Publications, Book 71, hadeeth 5700

112. Messlinger K, Fischer MJ, Lennerz JK (2011) Neuropeptide effects in the trigeminal system: pathophysiology and clinical relevance in migraine. Keio J Med 60: 82-89.

113. Sicuteri F, Fanciullacci M, Geppetti P, Renzi D, Caleri D, et al. (1985) Substance $\mathrm{P}$ mechanism in cluster headache: evaluation in plasma and cerebrospinal fluid. Cephalalgia 5: 143-149.

114. Al-Albani MN (1996) Series of correct series of hadeeths (1 $1^{\text {st }}$ edn) Library of knowledge for publication 6: 561 .

115. Higashi Y, Sasaki S, Sasaki N, Nakagawa K, Ueda T, et al. (1999) Daily aerobic exercise improves reactive hyperemia in patients with essential hypertension. Hypertension 33: 591-597.

116. Huang CL, Kuo E (2007) Mechanism of hypokalemia in magnesium deficiency. J Am Soc Nephrol 18: 2649-2652. 